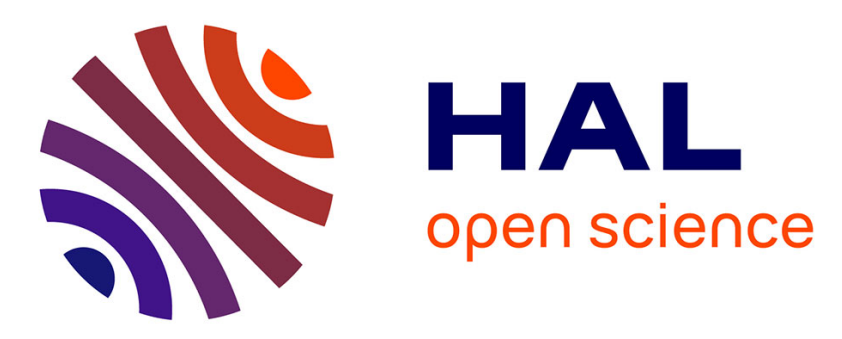

\title{
Description and evaluation of a surface runoff susceptibility mapping method
}

\author{
L.R. Lagadec, Pierre Patrice, Isabelle Braud, B. Chazelle, L. Moulin, J. \\ Dehotin, E. Hauchard, Pascal Breil
}

\section{- To cite this version:}

L.R. Lagadec, Pierre Patrice, Isabelle Braud, B. Chazelle, L. Moulin, et al.. Description and evaluation of a surface runoff susceptibility mapping method. Journal of Hydrology, 2016, 541 (PART A), pp.495509. 10.1016/j.jhydrol.2016.05.049 . hal-02605193

\section{HAL Id: hal-02605193 https://hal.inrae.fr/hal-02605193}

Submitted on 16 May 2020

HAL is a multi-disciplinary open access archive for the deposit and dissemination of scientific research documents, whether they are published or not. The documents may come from teaching and research institutions in France or abroad, or from public or private research centers.
L'archive ouverte pluridisciplinaire HAL, est destinée au dépôt et à la diffusion de documents scientifiques de niveau recherche, publiés ou non, émanant des établissements d'enseignement et de recherche français ou étrangers, des laboratoires publics ou privés. 


\section{Special Issue of Journal of Hydrology:}

Title:

Authors:

Lilly-Rose Lagadec ${ }^{1,2, *}$, Pierre Patrice ${ }^{2}$, Isabelle Braud ${ }^{2}$, Blandine Chazelle. ${ }^{1}$, Loïc Moulin ${ }^{1}$, Judicaël

${ }^{1}$ SNCF Réseau, Engineering and Project Direction, 6 avenue François Mitterrand, 93574, La Plaine

${ }^{2}$ IRSTEA, HHLY, Hydrology-Hydraulic Department, Centre de Lyon-Villeurbanne, 5 rue de la Doua, 69626 Villeurbanne, France.

${ }^{3}$ Agglomeration community of Le Havre (CODAH), 19 rue Georges Braque 76085 Le Havre Cedex, France / UMR M2C 6143 CNRS Geology Department University of Rouen, France Correspondence to: Lilly-Rose Lagadec (Irlagadec@gmail.com)

Keywords: surface runoff; soil erosion; GIS mapping; evaluation; susceptibility map; transportation 
Author-produced version of the article published in Journal of Hydrology, Volume 541, Part A, October 2016, Pages 495-509 The original publication is available at http://www.sciencedirect.com/ doi : 10.1016/j.jhydrol.2016.05.049

C. This manuscript version is made available under the CC-BY-NC-ND 4.0 license

\section{Abstract}

Surface runoff is the hydrological process at the origin of phenomena such as soil erosion, floods out of rivers, mudflows, debris flows and can generate major damage. This paper presents a method to create maps of surface runoff susceptibility. The method, called IRIP (Indicator of Intense Pluvial Runoff, French acronym), uses a combination of landscape factors to create three maps representing the susceptibility (1) to generate, (2) to transfer, and (3) to accumulate surface runoff. The method input data are the topography, the land use and the soil type. The method aims to be simple to implement and robust for any type of study area, with no requirement for calibration or specific input format. In a second part, the paper focuses on the evaluation of the surface runoff susceptibility maps. The method is applied in the Lézarde catchment $\left(210 \mathrm{~km}^{2}\right.$, northern France) and the susceptibility maps are evaluated by comparison with two risk regulatory zonings of surface runoff and soil erosion, and two databases of surface runoff impacts on roads and railways. Comparison tests are performed using a standard verification method for dichotomous forecasting along with five verification indicators: accuracy, bias, success ratio, probability of detection, and false alarm ratio. The evaluation shows that the susceptibility map of surface runoff accumulation is able to identify the concentrated surface runoff flows and that the susceptibility map of transfer is able to identify areas that are susceptible to soil erosion. Concerning the ability of the IRIP method to detect sections of the transportation network susceptible to be impacted by surface runoff, the evaluation tests show promising probabilities of detection (73 to 90\%) but also high false alarm ratios (77 to 92\%). However, a qualitative analysis of the local configuration of the infrastructure shows that taking into account the transportation network vulnerability can explain numerous false alarms. This paper shows that the IRIP method can be a valuable tool to facilitate field analysis and perform surface runoff zonings and opens interesting prospects for the use of the IRIP method in a context of risk management. 
Author-produced version of the article published in Journal of Hydrology, Volume 541, Part A, October 2016, Pages 495-509 The original publication is available at http://www.sciencedirect.com/ doi : 10.1016/j.jhydrol.2016.05.049

C. This manuscript version is made available under the CC-BY-NC-ND 4.0 license

\section{Introduction}

Intense surface water runoff is a hydrological process which can generate major damage. When the surface water concentrates, it gains enough energy to erode soil particles, which makes the water denser and more powerful (Wischmeier, 1959). Intense surface runoff includes phenomena such as soil erosion, floods out of river networks, mudflows, and debris flows. According to the Gaspar French database ${ }^{1}$, which collects information on natural disasters at a district level, around $40 \%$ of flood damage is due to intense surface runoff in France (Dehotin and Breil, 2011a). Surface runoff often impacts populations and infrastructures such as homes or transportation networks (Chazelle et al., 2014). The environment can also be impacted by surface runoff through soil loss and the transfer of pollutants contained in soils.

For this study, surface runoff is defined as water from precipitation which does not infiltrate into the soil and flows on the surface until it reaches a permanent river. This hydrological process can also be called overland flow (Hewlett, 1982). Two surface-runoff generation processes can be distinguished: infiltration excess overland flow, when the rain intensity is higher than the soil infiltration capacity, called hortonian runoff (Horton, 1933); and saturation overland flow, when soil storage capacity is limited or the soil is already saturated (Hewlett and Hibbert, 1967). These processes are difficult to observe in the field because they occur quickly and they can occur simultaneously (Cros-Cayot, 1996). In general terms, surface runoff is a difficult-to-measure phenomenon (Dehotin et al., 2015). Once surface water flows downstream, it can infiltrate, be transferred or be accumulated depending on topographical and micro-topographical features - or join a watercourse or drainage system. Surface runoff can flow in a diffuse or concentrated manner. Many factors can influence or reduce surface runoff in a catchment: soil characteristics (type, thickness, roughness, permeability) (Piney, 2009), initial water content, land use (vegetation, urbanization, agricultural land), geology (Onda et al., 2001), topography, geomorphology (ability to concentrate, plateau/valleys distribution) (Douvinet et al., 2008), and rainfall characteristics (intensity, frequency, duration) (Galevski, 1955).

In the field of risk management, some terms can have a wide range of definitions, depending on the field of application (Christensen et al., 2003; Thywissen, 2006). The following definitions are retained. Firstly, intense surface runoff is a natural hazard, which means a natural event, potentially dangerous, occurring randomly in space and time (UNDRO, 1979). Risks induced by intense surface runoff are impacts that surface runoff may potentially cause to society (people, goods, environment, economy, etc.). A risk is the combination of a hazard and a vulnerability (UNDHA, 1992). Vulnerability

\footnotetext{
${ }^{1}$ https://www.data.gouv.fr/fr/datasets/gaspar/
} 
Author-produced version of the article published in Journal of Hydrology, Volume 541, Part A, October 2016, Pages 495-509 The original publication is available at http://www.sciencedirect.com/ doi : 10.1016/j.jhydrol.2016.05.049

C. This manuscript version is made available under the CC-BY-NC-ND 4.0 license

is often defined as a measure to assess the quantity of loss potentially generated by a hazard (Buckle et al., 2000; Society for Risk Analysis, 2015). In this study, the vulnerability of the transportation network refers to its structural vulnerability; the higher the vulnerability, the higher the possibility of being physically damaged.

In the scientific literature, there are many models for the simulation or mapping of surface runoff processes. They may be classified into various approaches: naturalistic, topographic, a combination of criteria or hydrological modeling. Naturalistic approaches often provide results consistent with the reality but they require a very good understanding of the study area, can be applied to rather small areas, and are difficult to replicate (Abudi et al., 2012; Dehotin et al., 2015a; Holzmann and Sereinig, 1997; Tetzlaff et al., 2007). Topographical approaches using information from Digital Elevation Models (Delahaye et al., 2002; Langlois and Delahaye, 2002; Pons et al., 2010) have the advantage of being simple and can be automated but the mapping of surface runoff needs to take into account many other parameters such as land use or soil type. Criteria combination approaches also remain relatively straightforward while taking into account multiple parameters. The review of existing methods reveals that most of them focus on water erosion or landslide (Akgun and Türk, 2010; Faulkner et al., 2010; Guillobez et al., 2000; Le Bissonnais et al., 2002; Schmocker-Fackel et al., 2007). Hydrological modeling techniques are both accurate and provide quantitative results including the time evolution of the processes (Carpenter et al., 1999; Cerdan et al., 2002; Dabney et al., 2011; DeRoo et al., 1996; Laflen et al., 1991; Smith et al., 1995). Some are extremely complex. They require significant computational time, calibration to be applied to different catchments, and a large quantity of data. This rapid overview shows that there are multiple methods for surface runoff mapping but the maps are either difficult to reproduce automatically, need many complex input data, or the method is focused on a specific phase of the phenomenon (the accumulation areas, the low infiltration areas or the erosion areas) and do not address all the aspects of the entire runoff process. For this reason, a method called IRIP for Indicator of Intense Pluvial Runoff (French acronym) has been developed to produce comprehensive mapping of areas susceptible to generate, to transfer, and to accumulate surface runoff without explicit hydrological modeling and using open access data (Dehotin et al., 2015a; Dehotin and Breil, 2011a). This automatic method can be applied to a large range of study area sizes with data at various resolutions. However, the validity and relevance of the produced maps must be evaluated carefully and rigorously.

The evaluation of hazard models is an important step in model developments. Indeed, model outputs can be used for stakeholder decision-making in risk management. The stakes are very high (cost of structural and organizational adjustments, safety risks) and wrong decisions can lead to serious consequences. It is essential to know the exact value of model outputs, that is, the assumptions 
Author-produced version of the article published in Journal of Hydrology, Volume 541, Part A, October 2016, Pages 495-509 The original publication is available at http://www.sciencedirect.com/ doi : 10.1016/j.jhydrol.2016.05.049 C. This manuscript version is made available under the CC-BY-NC-ND 4.0 license

made, the application range, and uncertainties related to the results. Globally, model evaluation suffers from a lack of methodological guidelines (Moriasi et al., 2007). For surface runoff hazard models, the evaluation is particularly complex because of the lack of surface runoff data. The phenomenon rapidity and scarcity make large-scale observation and instrumentation a complex issue (Dehotin et al., 2015a; Hudson, 1993). The IRIP method has already undergone numerous evaluations using in-situ measurements (Dehotin et al., 2015a; Laverne, 2013) and discharge data (Arnaud and Dehotin, 2011; Legros, 2014) but to go further in the evaluation procedure and to assess the relevance of the IRIP method from the point of view of risk assessment, the use of proxy data is suggested. Proxy data are data which are not direct measurements of the phenomenon but are related to it and provide large-scale evidence of the phenomenon occurrence (IPCC, 2003). Some studies in hydrology use proxy data to evaluate models, such as flooded road reports (Naulin et al., 2013; Versini et al., 2010a, 2010b), observations of gravitational hazards in mountainous areas (Defrance, 2014), and post-event surveys (Javelle et al., 2014; Ortega et al., 2009). Concerning the IRIP method evaluation, few comparisons have been performed with proxy data such as surface runoff impact locations on railways (Dehotin et al., 2015b) and natural disaster declaration locations from the Gaspar French database (Dehotin and Breil, 2011a). However, these tests have been performed for few case studies and remain qualitative. Indeed, the comparison between model outputs and proxy data generates technical issues: for example, how can data that are different in form and content and that do not carry the same information be compared reliably? The use of proxy data highlights the lack of methodological framework but also shows the valuable contribution of this type of data for model evaluation.

The first objective of this paper is to present the IRIP method for surface runoff susceptibility mapping. The second objective is to evaluate the IRIP maps by comparison with different types of proxy data available on the study area: regulatory zonings of surface runoff and soil erosion and databases of surface runoff impacts on roads and railways. The paper proposes an evaluation method that allows quantitative evaluation of the spatial information contained in the IRIP maps. Finally, development paths are discussed to adapt the IRIP method as a tool for risk management.

\section{Materials and Methods}

\subsection{The IRIP Method}

IRIP is a method to map the spatial distribution of areas susceptible to surface runoff. The IRIP method concept is based on the creation of three susceptibility maps which represent surface runoff generation, transfer, and accumulation. Note that, to obtain a hazard map, the rainfall must be taken into account and to get a risk map, the hazard map must be combined with the stakes of the study 
area and their vulnerabilities. These two aspects are not considered in the present study, which only focuses on the susceptibility maps provided by the IRIP method.

Each susceptibility map (generation, transfer, and accumulation) is created by combining five indicators, summarised in Table 1 (columns 1\&2). Each indicator is classified in two categories favourable (1) or not favourable (0) to surface runoff (Table 1, col 3), providing a binary map. The five maps are subsequently assembled to produce a surface runoff susceptibility map from 0 (not susceptible) to 5 (very susceptible). This method is applied for the three IRIP maps, as represented in Figure 1. After reclassification, the generation map becomes an input indicator for the two other maps of transfer and accumulation. The reclassification proceeds as follows: a pixel is favourable (score $=1$ ) if the generation susceptibility levels in its relative drained area have a mode (the most present value of the distribution) higher than a user-defined susceptibility level ( 3 by default). The use of the generation map as an input for the two others means that susceptibility to transfer or accumulation is conditioned by a sufficiently high susceptibility for surface runoff generation. This allows the incorporation of an upstream-downstream logic in the maps. For each map, the five indicators have been chosen based on field knowledge (Dehotin et al., 2015a), literature review (Dehotin and Breil, 2011b), and multiple combination tests.

For the surface runoff generation map, the five indicators are derived from factors influencing runoff generation: soil properties, topography, and land use. Three indicators represent the impact of soil properties and are based on soil erosion model parameters (Le Bissonnais et al., 2002; Le Gouee et al., 2010; Nearing et al., 1989). The erodibility indicator in the generation map represents the possibility of the generated surface water combining with soil particles to generate a mudslide (Cerdà and Doerr, 2008). For agricultural plots, the erodibility indicator also represents the susceptibility of soils to create slaking crusts that are favourable to surface runoff generation. The topography indicator is an "or" combination of the slope and the topographic index, that is, the topography indicator is favourable if the slope is steep, if the topographic index is high, or both. Steep slopes are considered as favourable to surface runoff generation reflecting the reduced ability of water to infiltrate into the soil. The topographic index (Beven and Kirkby, 1979), $\ln (a / \operatorname{tanb})$, where $a$ is the upstream drained area and $b$ is the local slope, reflects the capacity at one point to evacuate water from upstream, that is, water storage-prone areas. Although the topographic index also uses the slope, the topography indicator in the IRIP method combines two different effects: slope and ability to store water. In order to be able to apply the method in every catchment without local knowledge, relative thresholds $\left(t_{1}, t_{2}\right)$ are used to distinguish topographic indicators (slopes, topographic index) as favourable or not. For each indicator, the distinction is made thanks to classification algorithms (MacQueen, 1967; Reuter et al., 2006). It permits dividing the study area 
Author-produced version of the article published in Journal of Hydrology, Volume 541, Part A, October 2016, Pages 495-509 The original publication is available at http://www.sciencedirect.com/ doi : 10.1016/j.jhydrol.2016.05.049

C. This manuscript version is made available under the CC-BY-NC-ND 4.0 license

into two categories of slopes or topographic indices depending on the local and surrounding pixel values. The land use indicator reflects the fact that urban and agricultural areas are considered as favorable to surface runoff generation. For urban areas, the generation map is recalculated to force soil permeability and thickness to be favourable in those areas, in the event that the areas have not been classified as favourable from the indicators derived from the soil map.

The susceptibility maps of surface runoff transfer and accumulation reflect surface water naturalflow dynamics. Both involve different mechanisms, acting often in the opposite direction, such as slope and break of slope. This is why two maps are created. The choice of the corresponding indicators is based on detailed analyses of past intense surface runoff events (Dehotin and Breil, 2011b) where slope, break of slope, catchment compactness, and artificial linear axes appeared as main factors to produce intense phenomena. The computation of the break of slope proceeds as follows: in each pixel, the mode of the slope value distribution in the upstream area drained by this pixel is computed and compared to the local slope value of the pixel. If the upstream slope mode is smaller (respectively higher) than the local slope, the pixel is indicated as convex (respectively concave), and is assigned 1 for the transfer map ( 1 for the accumulation map). The transfer map uses the Horton form factor (Horton, 1932), which is the ratio of area to length of the sub-watershed defined by the drained area at the considered pixel. The artificial linear axes are taken into account in the transfer map because of their role in surface runoff interception and displacement (Cerdà, 2007; Pams-Capoccioni et al., 2015).

Finally, the input data of the IRIP method are: a DEM, a land use map, a soil map, and optionally the artificial drainage network (Figure 1). The input data resolution can be adapted to the size of the study area. For a relatively large study area, the analyst can proceed as follows: maps can be initially produced for the whole study area with a coarse resolution DEM (i.e. cells larger than 10 meters) and then areas susceptible to surface runoff can be focussed on with a higher resolution DEM (i.e. cells smaller than 10 meters). These susceptibility maps reflect a certain description of the surface runoff mechanisms in a watershed. Given the considered indicators, the IRIP map of surface runoff generation highlights the areas more susceptible to generate water on the soil surface. The IRIP transfer map highlights the areas where surface water can move and gain speed, and the IRIP map of accumulation highlights the areas where there is a tendency for a reduction in surface water velocity and water level increases. The method aims to be simple to implement, using open-access input data and to be robust regardless of the data quality and uncertainty. This is the reason why more complex methods such as weighting the indicators or classifying them into more than two categories were not retained in the first version of the method. However, the method remains open for adaptation regarding the user knowledge, but the default parametrization permits applying the method 
whatever the study area. In this paper, the relevance of the IRIP maps is assessed based on this first version of the method.

\subsection{The Study Area}

The Lézarde catchment $\left(210 \mathrm{~km}^{2}\right)$, located between the English Channel and the Seine river, is wellknown for being subject to flooding predominantly generated by surface runoff (Delahaye et al., 2002; Douvinet et al., 2014; Le Gouee et al., 2010). The catchment morphology is composed of large plateaux and narrow valleys (Figure 2). The permanent hydrographic network is very short but the temporary network consists of an extremely dense talweg network. The area was formed during the last glacial era during which the ice melt eroded the soil surface (Auzet et al., 1993). Soil characteristics of the catchment are mostly silt and clay with flint stones. Locally, there are sandy loams that increase soil erosion processes. The geology of the territory is composed of karst which forms a complex active underground river network (Hauchard and Laignel, 2008). The climate of the whole Seine-Maritime region is characterised by two main rainfall seasons: summer and autumn. In summer, rainfall durations are shorter than in autumn but more intense, whereas in autumn the rainfall patterns are less intense but last for long periods, leading to soil saturation (Douvinet, 2008). These two rainfall patterns can both generate storm runoff floods but involve different mechanisms. In terms of land use, a large part of the Lézarde catchment is made up of agricultural areas. A soil crusting process takes place between planting cycles, influenced by an exposed and high silt rate in the top soil, making the soil surface almost impervious (Robinson and Phillips, 2001). In addition, roads and villages were built in exposed areas: many roads are located in talwegs and villages are located at the downstream end of catchments or sub-catchments. Consequently, flooding in the catchment tends to generate major damage.

In the Lézarde catchment, the IRIP maps were produced using a 25-meter DEM from the French National Institute of Geograhy ${ }^{2}$. The land use map ${ }^{3}$ is on the scale of 1/5000 in rural areas and 1/2000 in urban areas. The soil map is the pedologic map from the French National Institute for Agronomic Research (INRA) at the scale of 1/1000000 (Dupuis, 1969). To calibrate the method in the Lézarde catchment, some assumptions are made based on literature review, discussions with local stakeholders and multiple tests on the IRIP maps. For the soil indicators, the distinction between favorable or not is based on soil data analysis (Daroussin and King, 1997; Jamagne et al., 1995). The slope threshold for the distinction between favorable or not was fixed at $4 \%$, based on surface runoff studies on the Lézarde catchment (Hauchard, 2002). For the land use indicator, the urbanized and

\footnotetext{
${ }^{2}$ http://professionnels.ign.fr/bdalti

3 http://mos.hautenormandie.fr/Presentation
} 
the agricultural areas are considered as favorable to surface runoff (Hauchard et al., 2002). For the Horton form factor, the index is considered as favorable to surface runoff transfer for values larger than 0.15 (fixed from tests with IRIP maps). Only roads and railways are used for the artificial linear axes, as data on agricultural drainage are not available at this scale. The flow accumulation threshold was chosen at $0.5 \mathrm{ha}$, a value small enough to detect surface runoff close to the catchment head. These choices are explained further in the discussion and perspectives section.

\subsection{The Comparison Data}

The data sets used for the evaluation of the surface runoff susceptibility maps are presented here. Four data sets are used: two regulatory zonings of surface runoff and erosion risks and two data sets of surface runoff impacts on roads and railways networks. The two regulatory zonings are provided by the agglomeration of Le Havre ${ }^{4}$ and the local association of the Pointe de Caux Catchment ${ }^{5}$ (SMBV) respectively. They are part of the natural risk prevention plan (Departmental Directorate of Seine-Maritime, 2013a; Departmental Directorate of Seine-Maritime, 2013b). These regulatory zonings take into account both exposure of assets at risk and their probability of damage. The database of surface runoff impacts on roads is provided by the SMBV and the database of surface runoff impacts on railways is provided by the French National Railway Company (SNCF Réseau).

\subsubsection{The Surface Runoff Regulatory Zoning}

The surface runoff zoning was established in a qualitative manner. All the surface runoff axes, where water can concentrate (i.e. the dry talwegs), were identified by field expertise and historical information on past events (Hauchard, 2002). Then, to create the surface runoff zoning, a buffer area around surface runoff axes was designed. The buffer size ranges from 5 to 80 meters and the value was locally chosen thanks to field knowledge. Finally, hydrological modeling was used only in areas with high exposure levels to obtain water levels and flow velocities, but the latter information is not used in the evaluation procedure, where only the zoning map is used. This zoning map does not take into account the presence of protection structures against floods.

For the comparison with IRIP, the surface runoff zoning is compared with the IRIP map of surface runoff accumulation susceptibility. The zoning is created from the dry talweg axes, which are axes of water concentration and where, locally, water velocity reduces and subsequently water depth increases. This effect is included in the IRIP map of accumulation and is represented by the IRIP indicators: flow accumulation, topographic index, and concave break of slopes. For the comparison

\footnotetext{
${ }^{4}$ http://www.codah.fr/article/lutte-contre-les-inondations

5 http://www.smbv-pointedecaux.fr/web/decret erosion2.html
} 
271 tests, the permanent hydrographic network is also masked. Indeed, the accumulation map also

272 detects the rivers but the comparison rather focuses on hillslopes where surface runoff occurs.

\subsubsection{The Soil Erosion Regulatory Zoning}

274

275

276

277

278

279

280

281

282

283

The soil erosion zoning was created using two soil erosion models: the RUSLE model from USDA (Dabney et al., 2011) and the STREAM model from INRA (Cerdan et al., 2002). The models have been adjusted using erosion traces from aerial photographs. The results of the two models have been combined and validated by knowledge from local experts. The soil erosion hazard map was crossed with a map of the territory vulnerabilities to obtain the soil erosion zoning map.

For the comparison with IRIP, the soil erosion zoning is compared with the IRIP map of surface runoff transfer susceptibility. Indeed, the soil erosion is a process influenced by the occurrence of surface runoff with a water level and a speed sufficient to transport materials. This effect is included in the IRIP map of transfer and is represented by the IRIP indicators: compactness index and convex break of slopes. For the comparison tests, the urban areas are masked because the regulatory zoning focuses on rural areas.

\subsubsection{The Databases of Impacts on Transportation Networks}

The database of flooded roads is made up of 31 road sections and was created after an intense rainfall event by witness interviews and field expertise. On October 13, 2013, the Lézarde catchment was subject to a significant rainfall event, generating intense surface runoff. The return period of the event was estimated to be more than a hundred years by the Predict weather services (Gouvazé and SMBV, 2013). The high-intensity rainfall affected mainly the three sub-catchments located in the north of the Lézarde catchment, upstream of the Lézarde River (highlighted in yellow in Figure 3). Up to $70 \mathrm{~mm}$ fell in 6 hours in this area and the three rain gages $(1,2,3)$ recorded 160, 156 and $100 \mathrm{~mm}$ respectively in 24 hours. Thus the comparison tests focus only on these 3 sub-catchments. The road sections in the database were temporarily cut off by floodwater and impracticable or even swept away by floodwater (photos at the bottom of Figure 3).

The database of impacts on the railway is made up of 41 incidents listed from 1995 to 2012. These 41 incidents are observed in 21 railway sections, the incidents occurring sometimes at the same location. This database is not exhaustive and contains uncertainties on incident locations, particularly in relation to the source of flooding and the length of railway that was affected. The recorded types of incidents are embankment erosion, flooded platforms or mudslides. For the comparison tests, these two databases are compared to the IRIP maps of transfer and accumulation susceptibility, because we assume that accumulation as well as transfer of water can generate damage. 
This section highlights that the four data sets differ greatly in form and content. The next section describes the methodology used to compare these four data sets to the IRIP surface runoff susceptibility maps.

\subsection{The Evaluation Method}

To evaluate the IRIP method, the surface runoff susceptibility maps are compared to a set of comparison data. In this section, the comparison tests and the verification indicators are presented, as well as the data formatting process that is required to compare different data types.

\subsubsection{Comparison Tests}

To assess the correspondence between the IRIP maps and the comparison data, contingency tables are created and associated verification indicators are computed. This method is inspired by the standard verification methods for dichotomous (yes/no) forecasts (Hogan and Mason, 2012; Stanski et al., 1989). Table 2 shows the theoretical contingency table created for each comparison test. The "observed event" columns represent information from the comparison data. For example, in the case of the zonings, "yes" means inside the zoning and "no" means outside. In the case of the impact databases, "yes" means the impacted network section and "no" means the remaining parts of the transportation network that were not impacted. The "IRIP" lines represent information from the IRIP maps. For the tests, the IRIP maps are converted into dichotomous results, with "yes" being pixels with a susceptibility level greater than or equal to 4 and "no" being pixels lower than 4 . The threshold of 4 is chosen regarding the low proportion of susceptibility level values of 4 and 5 over the catchment. Pixel values of 4 and 5 represent $4 \%$ of the study area in average, whereas pixel values of 3 represents $30 \%$ of the study area. In the theoretical contingency table, for comparisons with the regulatory zonings (respectively, comparisons with the impacts on the transportation network), true positives are IRIP pixels with high susceptibility levels located inside the zonings (resp. inside the impacted network sections). True negatives are IRIP pixels with low susceptibility levels located outside the zonings (resp. inside the not impacted network sections). False positives are IRIP pixels with high susceptibility levels located outside the zonings (resp. inside the not impacted network sections). Finally, false negatives are IRIP pixels with low susceptibility levels located inside the zonings (resp. inside the impacted network sections). From the contingency tables, five verification indicators are computed: accuracy, bias, success ratio (SR), probability of detection (POD), and false alarm ratio (FAR). POD and FAR are computed only when comparing with the impacts on the transportation network, in order to assess the ability of the IRIP method to detect areas susceptible to be impacted. The indicators are presented in Table 3 along with the formulas and the result interpretations. 
Author-produced version of the article published in Journal of Hydrology, Volume 541, Part A, October 2016, Pages 495-509 The original publication is available at http://www.sciencedirect.com/ doi : 10.1016/j.jhydrol.2016.05.049

C. This manuscript version is made available under the CC-BY-NC-ND 4.0 license

2.4.2. Data Formatting

337

338

339

340

341

342

343

344

345

346

347

348

349

350

351

352

353

354

355

356

357

358

359

360

361

Concerning comparison tests with the regulatory zonings, the surface runoff regulatory zoning is compared with the IRIP map of accumulation susceptibility. The soil erosion zoning is compared with the IRIP map of transfer susceptibility. For each comparison, the contingency table is computed by using two different thresholds of IRIP susceptibility level: for pixel values greater than or equal to 4 and for pixel values of 5 only. Moreover, for each comparison, the contingency table is computed by using three different sizes of buffer area around the zonings: 0, 25, and 50 meters. Buffer areas are used in order to compensate for uncertainties in data comparison. Uncertainties can come from the fact that different data formats are compared (raster for the IRIP map and polygons for the zonings). This can lead to uncertainty when overlapping the data. Uncertainties can also come from the input data used for the creation of the IRIP maps and the zonings (i.e. DEM resolution). Buffer area sizes of 0,25 , and 50 meters correspond to a shift of zero, one or two pixels of the IRIP maps.

Concerning the impact databases, comparison tests are performed separately for roads and railways, and for each test, the impact locations are compared with the IRIP maps of transfer and accumulation simultaneously. The comparisons are performed using the transportation network as the reference study area, and not the whole catchment. In order to perform the comparison, the linear transportation networks are transformed to polygons, using a buffer. Two buffer area sizes of 25 and 50 meters on both sides of the transportation network were considered. Concerning the IRIP maps, an area is considered susceptible to surface runoff if there is a spatial persistence of pixels with high susceptibility levels, and not if there is only one isolated pixel with a high value. The pixel spatial persistence on the IRIP maps of transfer and accumulation is taken into account as follows: a buffer area of 25 meters is drawn around all pixels of values 4 and 5 and, if an isolated pixel with its buffer area is not intercepted by another buffer, the pixel is removed (Figure 4a). Finally, four contingency tables are computed for roads and railways with two different buffer area sizes around the transportation network, focusing on the overlapping surface between the IRIP maps and the impacted road sections, as presented in Figure $4 \mathrm{~b}$.

\section{Results}

\subsection{Application of the IRIP method in the Lézarde catchment}

The susceptibility map of surface runoff generation (Figure 5) shows that the catchment presents a high susceptibility to generate surface runoff. About $88 \%$ of the study area has pixels with a score above 3 , on a scale ranging from 0 to 5 . The pixels with a highest score are located in the urban areas 
of Le Havre and Montivilliers. We can also see high susceptibility levels in the western part of the catchment and in the valley sides. Although the valley sides are occupied by forest, they present a high susceptibility to generate surface runoff because of soil properties and steep slopes. Despite the flat topography of the plateaux upstream of the catchment, they present a high susceptibility to surface runoff generation with values of 3 and 4 locally because of the soil properties and the agricultural land use. Occupying approximately two thirds of the catchment, these plateaux are responsible for the largest part of the generated surface water.

The susceptibility map of surface runoff transfer (Figure 6) mainly shows high levels in the valley sides, where slopes are steep and break of slopes are convex. This map shows low susceptibility values of transfer in the plateaux and in the valley bottom. The high susceptibility areas actually highlight the sides of the main talwegs and a great deal of small talwegs even very close to the head of the catchment.

The susceptibility map of surface runoff accumulation (Figure 7 ) shows that plateaux are prone to accumulate surface runoff with values equal or greater than 3 on a large part of the catchment. These susceptibility levels are due to low slopes, concave break of slopes, and a high topographic index in the upstream portions of the catchment. Permanent rivers are identified with the level 5, and an extremely dense talweg network can be distinguished with the susceptibility levels 4 and 5 . In upstream talwegs, susceptibility levels 4 and 5 are still visible but seem to be more spread out. The map highlights that the valley sides are not favorable to surface runoff accumulation in contrast to the map of transfer.

\subsection{Evaluation of the IRIP maps}

In this section, the IRIP maps are first compared to the regulatory zonings, in order to assess the ability of the map of accumulation to identify areas prone to concentrated surface runoff (Figure 8) and to assess the ability of the map of transfer to identify areas prone to soil erosion (Figure 9). Then, the IRIP maps are compared to the databases of impacts on the transportation network to assess the ability of the IRIP method to identify road and railway sections susceptible to be impacted by surface runoff (Figure 10).

The superimpositions of the IRIP maps and the two regulatory zonings (Figures 8 and 9) show a good visual correlation and a relevance of the spatial distribution of the IRIP susceptibility levels. Table 4 presents the results of the comparison between the two regulatory zonings and the IRIP maps. Six comparison tests are performed for the surface runoff zoning and six for the soil erosion zoning: with the three buffer area sizes and considering pixels of value 4 and 5, and 5 only. Three indicators are 
400

401

402

403

404

405

406

407

408

409

410

411

412

413

414

415

416

417

418

419

420

421

422

423

424

425

426

computed for each test: accuracy, bias, and success ratio. Results show that for that comparison with the surface runoff zoning, the accuracy ranges from 0.68 to 0.86 and, for the comparison with the soil erosion zoning, accuracy ranges from 0.36 to 0.69 . Biases for all the tests are lower than 1 and range from 0 to 0.41 . The success ratio represents the number of high susceptibility level pixels that are located inside the zoning, regarding the whole study area. It ranges from 0.41 to 0.92 . The best success ratio for the accumulation map is 0.92 and is obtained when using a 50-meter buffer around the surface runoff zoning and when considering only pixels with a value of 5 . The best success ratio for the transfer map is also 0.92 and obtained with the same conditions. Moreover, a success ratio of 0.91 is obtained when considering pixels of value 4 and 5 , using a 50-meter buffer. Concerning the comparison with the impacts on the transportation network, Table 5 shows the results of the five verification indicators for the four tests: comparison with the database of impact on roads and with the database of impacts on railways, using two different buffer area sizes for both of 25 and 50 meters around the transportation network. For the analysis of impacts on roads, comparison tests show accuracy of about 0.6 and 0.3 for impacts on railways. Biases are greater than 1 and range approximately from 3 to 9 . Success ratios are lower than 0.25 for both transportation networks. Probabilities of detection range from 0.7 to 0.9 , and figures are similar for the false alarm ratios. The best probability of detection for the impacted road sections is 0.73 using a 25 -meter buffer around roads, and the best one for the impacted railway sections is 0.9 using a 50-meter buffer around railways.

These results are discussed in the next section in the light of the assumptions made for the comparison tests and in the light of the high false alarm ratios for the comparison tests with the impact databases. Moreover, suggestions are presented to go further in the evaluation method and in the development of the IRIP method.

\section{Discussion and Perspectives}

\subsection{Result Discussion}

\subsubsection{Comparisons with the Regulatory Zonings}

The success ratio is the number of pixels with high susceptibility levels located inside the zonings regarding the total number of pixels with high susceptibility levels in the catchment. So, without 
Author-produced version of the article published in Journal of Hydrology, Volume 541, Part A, October 2016, Pages 495-509 The original publication is available at http://www.sciencedirect.com/ doi : 10.1016/j.jhydrol.2016.05.049

C. This manuscript version is made available under the CC-BY-NC-ND 4.0 license

using a buffer, obtaining success ratios of 0.72 and 0.64 is already promising. Using a buffer area of 50 meters around the zonings makes it possible to obtain success ratios above 0.9 . This shows that a large number of high susceptibility IRIP pixels are located very close to the regulatory zonings and that uncertainties in the high susceptibility level locations could be interpreted as between 0 and 2 pixels. These success ratios are extremely promising considering that the two maps are created using very different techniques and that they do not focus exactly on the same areas. The soil erosion zoning focuses on agricultural areas, and the surface runoff zoning focuses on talweg axes, whereas the IRIP method takes into account the whole catchment. Different results are obtained when considering pixel values of 5 and pixel values of 4 and 5 together. The choice of the susceptibility level depends on the information sought. Few pixels with a value of 5 are present in the catchment. They underestimate the global sensitivity of the catchment (bias close to zero), but they are more likely to indicate the localization of the areas that are highly susceptible to surface runoff. Concerning the IRIP map of accumulation, Figure 8 shows that the pixels are located precisely inside the zoning in the downstream part of the catchment but, in the catchment headwaters, pixels with a value of 4 are spread and are located outside the zoning. This spatial persistence of pixel values of 4 could indicate the beginning of a talweg that is not well defined in the landscape. Further comparison tests and field analysis must be undertaken to confirm this hypothesis.

Moreover, Figure 9 shows that a considerable section of areas contained in the erosion zoning is not correlated with the IRIP map of transfer, but seems to fit with the IRIP map of accumulation (Figure 11). Indeed, these areas present lower slopes, concave break of slopes, high topographic indices, and high flow accumulations. The soil erosion zoning gives a map of soils prone to erosion but, depending on the areas, erosion mechanisms and impacts can be different. The transfer map could emphasize incision susceptibility and the accumulation map could localize the deposit areas. Field analysis must be undertaken to better assess the ability of the IRIP maps to identify different erosion processes, but knowing the spatial distribution of the dominant processes could permit adapting the erosion prevention techniques in terms of the mechanisms involved.

Finally, the comparison with the two regulatory zonings shows that the maps produced with the IRIP method seems to be relevant in identifying areas susceptible to surface runoff. Moreover, susceptibility levels of 5 seem to indicate with a certainty of $90 \%$ an area susceptible to concentrative surface runoff (for the IRIP map of accumulation) and an area susceptible to soil erosion (for the IRIP map of transfer) with a spatial accuracy from 0 to 2 pixels. 
Author-produced version of the article published in Journal of Hydrology, Volume 541, Part A, October 2016, Pages 495-509 The original publication is available at http://www.sciencedirect.com/ doi : 10.1016/j.jhydrol.2016.05.049

C. This manuscript version is made available under the CC-BY-NC-ND 4.0 license

\subsubsection{Comparisons with Impacts on the Transportation Network}

466 The probability of detection is the ratio of good detection over the total observed impacts. Obtaining 467 probabilities of detection of 0.7 for road impacts and 0.8 for railway impacts is promising. The IRIP method seems to be relevant in identifying areas susceptible to surface runoff. However, success ratios are low due to a significant number of false alarms (i.e. false positives). The highly significant false alarm ratios and the overestimation are discussed.

First, these results come from the fact that the IRIP method gives susceptibility maps regarding soil surface predisposition, but the occurrence of a surface runoff-related impact depends on the rainfall spatial variability. For the rainfall event of October 13,2013 , it is assumed that rainfall was spatially homogeneous in the three sub-catchments, but this hypothesis is no more realistic for the railway network because the study area is wider and the database ranges in time from 1995 to 2012, when rainfall events are not likely to have been homogeneous. This can explain why higher false alarm ratios are obtained for the analysis of railway impacts. Moreover, working with proxy data involves uncertainties. For example, the databases may suffer from a lack of exhaustiveness in the number of reported impacts. In that case, impacts only are reported, whereas some network sections could have been affected by floodwater without being damaged and without network managers being informed. In addition to this, high false alarm ratios can come from the fact that the IRIP maps, which represent a susceptibility of surface runoff occurrence, are compared to an impact which is an effective risk. It is essential to take the structural vulnerability of roads and railways into account for a better assessment of the IRIP maps' ability to identify impacted sections.

Concerning the impacted roads analysis, more than 40 hydraulic structures are present over the three sub-catchments where intense rainfall occurred on October 13, 2013. They probably played an important role in the protection of the road network. Figure 10 shows the road network of the three sub-catchments along with the hydraulic structure locations. Post-event investigation allowed reporting whether or not the hydraulic structures have played their protective role. Green points indicate that the structure did not overflow; orange points indicate that it overflowed. This information can already explain why some road sections that appear susceptible to surface runoff with the IRIP method have not been reported as impacted. For example, in Figure 12, the A photo (corresponding to the A area on Figure 10) was taken just after the event and shows that the dam closing a reservoir is at one meter below the overflow. Thus, it could have protected this road section against floodwater. Further discussions with the river basin managers helped to explain some other false alarms. Figure 12 shows photos of three road sections $(B, C$, and $E$ areas can be seen in Figure 
Author-produced version of the article published in Journal of Hydrology, Volume 541, Part A, October 2016, Pages 495-509 The original publication is available at http://www.sciencedirect.com/ doi : 10.1016/j.jhydrol.2016.05.049

C. This manuscript version is made available under the CC-BY-NC-ND 4.0 license

10) that are considered as false alarms, despite the absence or dysfunction of protective structures. These photos show the configuration of roads within their environment, and give some clues about the vulnerability level of the sections regarding surface runoff. Photo B shows a large drainage ditch along the road. Photo $\mathrm{C}$ shows the road slightly elevated and the low point located in the grassland. These observations have been confirmed by the river basin managers. They also attested that the road section in the A area is regularly flooded by surface runoff during intense rainfall events and that the low point in the $D$ area is not located on the road but in the nearby field. The three impacts in the $\mathrm{E}$ area present the same configuration, that is, they transversally cut a dry talweg without any crossing structure. Photo E shows one of these intersections which still have the marks of an intense rainfall event, with standing water and soil deposits gathered in a mound. This configuration can explain why IRIP detects smaller susceptible areas than the reported section for these three impacts. The road may act as a barrier to the water flow path. Water can spread on both sides along the road and consequently flood a large section of the road. Using a DEM with a better resolution could help in identifying the local configuration. Finally, according to the river basin managers, the $\mathrm{F}$ area has been less exposed to the rainfall event, which can explain why it has not been reported as impacted.

For railways, the infrastructure configuration is more complex. Indeed, railway structures are highly constrained to keep a steady inclination and do not follow the natural topography. Railways are often built on embankments or in cuttings of varying height or depth. These configurations make railways vulnerable to surface runoff. To protect the railway infrastructure, multiple drainage devices or crossing structures are present all along the tracks to intercept flow paths and redirect them downstream. Therefore, to better identify railway sections susceptible to being impacted by surface runoff, the vulnerability must be characterized. The configuration of the infrastructure itself must be defined but the level of maintenance of the hydraulic structures must also be taken into account.

\subsection{Further Analysis with the Evaluation Method}

In the evaluation method, we need to compare data that do not have the same shape, do not give the same information, and that have been acquired using different techniques. Suitable indicators must be used to show the correspondence between data and to quantify it. For example, the success ratio gives information on whether or not the pixels with a high susceptibility level are located inside the zoning, but do not inform on the spatial distribution of the pixels regarding the zoning. For further evaluation, more complex indices could be used in order to improve the correlation analysis, for example by focusing on the shape of strong pixel areas or by analyzing pixel surroundings and mitigating isolated pixel effects (Hagen-Zanker, 2009; Hargrove et al., 2006). 
For the comparison tests, assumptions have been made and preliminary treatments have been carried out on the comparison data and on the IRIP map. Choices have been made for this study and must be discussed. First, pixels with a value of 4 and 5 are considered as high susceptibility levels. The significance of the susceptibility level 5 has been shown, but the significance of level 4 must be assessed. The significance of level 3 must also be assessed. Is it really not significant? Do levels 0,1 , and 2 indicate no surface runoff sensitivity? Moreover, for the comparison tests, buffer areas have been used. In order to avoid arbitrary choice on the buffer area size, the tests have been performed using 2 different sizes of 25 and 50 meters but more sizes could be tested, particularly negative buffer areas (reducing the zoning). For the comparison with the impacts on the transportation network, the hypothesis on the spatial persistence of high susceptibility levels indicating areas susceptible to be impacted must be assessed, along with the significance of isolated pixels. Do they bring valuable information or noise due to eventual input data inaccuracy?

Moreover, this study focuses on the transfer and the accumulation maps. For further evaluation, it would be interesting to focus on the susceptibility map to surface runoff generation and evaluate its ability to detect areas susceptible to generate significant quantities of surface water. For example, for the impact databases, it would be interesting to use the map of generation in a second phase, to help in distinguishing the sections most susceptible to be impacted among the ones detected by the maps of transfer and accumulation. Sections with a large area upstream with high susceptibility levels of surface runoff generation could be susceptible to be impacted with relatively major quantities of water or more often, or to be impacted first during a rainfall event. This hypothesis must be evaluated.

For further evaluation of the ability of the IRIP method to detect sections of the transportation network susceptible to be impacted by surface runoff, the structural vulnerability of the network must be characterised. A vulnerability indicator with different levels could be defined on the whole network, in order to combine hazards and vulnerability better and to correlate the location of impacts more effectively. Concerning the impacts, for such a comparison, further research must be undertaken to improve the completeness of the databases. In addition to these tests, particular events must be analyzed in greater detail in order to consider the influence of rainfall characteristics and better assess the surface runoff flow dynamic. To confirm the results obtained in this study, further comparison tests must be performed with different comparison data and for different study areas with other hydrological contexts. 
Several options for further developing and improving the IRIP method can be proposed. Concerning

564

565

566

567

568

569

570

571

572

573

574

575

576

577

578

579

580

581

582

583

584

585

586

587

588

589

590

591

592

593

594 the map of susceptibility to surface runoff generation, the valley sides appear as favorable to surface runoff whereas in reality the plateaux are the most important sources of surface runoff generation due to their relative importance in terms of proportion of the catchment size and to the fact that they are cultivated. They can generate substantial quantities of surface runoff which can be transferred to the valley throughout the extremely dense dry talweg network. It would be interesting to be able to integrate these geomorphology features in the IRIP method. For example, a computation of geomorphologic indexes could permit calibrating the method in terms of the plateau/valley distribution. The default configuration of the method is that steep slopes are favorable to surface runoff generation, which is relevant for mountainous areas, for example, but this choice could be inversed when working on large flat areas with large agricultural fields. Furthermore, the susceptibility map of surface runoff generation could be improved with better data accuracy. Especially the soil map, which is used for three of the five indicators, has a resolution of $1 / 1000000$ and gives only six different soil units in the Lézarde catchment. Moreover, it has been shown that the geology has an influence on surface runoff generation and transfer (Onda et al., 2001); it would be interesting to use this parameter in the IRIP method.

The map of susceptibility to surface runoff transfer takes the artificial linear axes as an input indicator because they can modify surface runoff directions, but if the data are available it would be interesting to add the urban and agricultural drainage network in this indicator. For the creation of this map, we currently use the Horton form factor to reflect the compactness effect of the subcatchment drained by each pixel ( 0.15 for our study). This index is not particularly satisfying because of its instability when computed on small drained areas. More adapted compactness indexes must be tested (Gravelius, 1914; Schumm, 1956), although their implementation can be complex with GIS techniques (Bardossy and Schmidt, 2002; Bendjoudi and Hubert, 2002). It would be better to use an index that is more adapted to a distributed computation.

In addition to these suggestions, the IRIP method could also be improved by making additional tests. For example, stability tests on the indicator thresholds could be performed to evaluate the threshold computation method. Changes in the input data resolution (DEM, land use map, and soil map) could be studied to evaluate how it affects the resulting maps. It would also be interesting, from a risk point of view, to cross the IRIP maps with meteorological data or land use change monitoring to provide real-time probability maps. 
This paper presents the IRIP method for surface runoff susceptibility mapping and its evaluation by comparison with different datasets. The method makes it possible to produce three maps representing different surface runoff mechanisms: generation, transfer, and accumulation. The maps' evaluation shows a significant correspondence between the IRIP map of accumulation and the surface runoff regulatory zoning and between the IRIP map of transfer and the soil erosion zoning. The comparison with data of impacts on the transportation network show promising probabilities of detection which confirm the relevance of the susceptibility maps. For an operational need of network monitoring, the structural vulnerability must be characterized to better discriminate the false alarms.

The IRIP method has shown promising results during the comparison tests, but can it be used as a tool for risk management? The IRIP method aims to be simple to implement and requires few input data that are widely available. Neither specific study area size nor calibration is required for a first use. In this sense, the IRIP method can be a useful tool to get a first understanding of the surface runoff mechanisms involved in a catchment and of their spatial distribution. Nonetheless, to go further in the map analysis, field expertise is required. The use of the IRIP maps regarding the usual hazard assessment methods can be complex because of the three types of maps and the susceptibility scale. In the other hand, working with three susceptibility maps of generation, transfer, and accumulation gives the opportunity to adapt risk mitigation techniques depending on the areas. In the areas prone to surface runoff generation, one can avoid soil imperviousness or facilitate infiltration with reservoir basins. In the surface runoff transfer areas, one can avoid bare soils and obstacles susceptible to be swept away. For accumulation areas, one can try to reduce stake vulnerabilities. Finally, this study highlights that a multidisciplinary approach is essential to assess surface runoff hazards. Likewise, a systemic view of the whole catchment is required, along with interactive work with the catchment stakeholders, to improve surface runoff risk management and to sustainably develop territories.

\section{Acknowledgments}

We thank all the project contributors: the agglomeration of Le Havre (CODAH) and the mixed association of the Pointe de Caux Catchment (SMBV) for their active contributions by providing highquality data sets and by remaining available to discuss and analyze the IRIP maps. We also thank the French National Railway Company (SNCF) for its interest in continuing the development of the IRIP 
628 method with the IRIP Rail project that funds the development of the iRIP software, and its

629 implementation for the French railway network. We thank Mark Cheetham, engineer at SNCF, for his

630 proofreading and remarks. Finally, we thank ANRT (Agence Nationale de la Recherche et de la

631 Technologie) for partial funding of this work. 


\section{References}

633

634

635

636

637

638

639

640

641

642

643

644

645

646

647

648

649

650

651

652

653

654

655

656

657

658

659

660

661

662

663

664

665

666

667

668

669

670

671

672

673

674

675

676

677

678

679

680

681

Abudi, I., Carmi, G., Berliner, P., 2012. Rainfall simulator for field runoff studies. J. Hydrol. 454, 76-81.

Akgun, A., Türk, N., 2010. Landslide susceptibility mapping for Ayvalik (Western Turkey) and its vicinity by multicriteria decision analysis. Environ. Earth Sci. 61, 595-611.

Arnaud, P., Dehotin, J., 2011. Surface runoff hazard estimation methods - Comparison of the SHYREG and the IRIP methods. IRSTEA Aix-en-Provence et IRSTEA Lyon.

Auzet, A.V., Boiffin, J., Papy, F., Ludwig, B., Maucorps, J., 1993. Rill erosion as a function of the characteristics of cultivated catchments in the north of France. Catena 20, 41-62. doi:10.1016/0341-8162(93)90028-N

Bardossy, A., Schmidt, F., 2002. GIS approach to scale issues of perimeter-based shape indices for drainage basins. Hydrol. Sci. J.-J. Sci. Hydrol. 47, 931-942. doi:10.1080/02626660209493001

Bendjoudi, H., Hubert, P., 2002. The Gravelius compactness coefficient: critical analysis of a shape index for drainage basins. Hydrol. Sci. J. 47, 921-930. doi:10.1080/02626660209493000

Beven, K.J., Kirkby, M.J., 1979. A physically based, variable contributing area model of basin hydrology / Un modèle à base physique de zone d'appel variable de l'hydrologie du bassin versant. Hydrol. Sci. J. 24, 43-69. doi:10.1080/02626667909491834

Buckle, P., Mars, G., Smale, S., 2000. New approaches to assessing vulnerability and resilience. Aust. J. Emerg. Manag. 15, 8.

Carpenter, T.M., Sperfslage, J.A., Georgakakos, K.P., Sweeney, T., Fread, D.L., 1999. National threshold runoff estimation utilizing GIS in support of operational flash flood warning systems. J. Hydrol. 224, 21-44. doi:10.1016/S0022-1694(99)00115-8

Cerdà, A., 2007. Soil water erosion on road embankments in eastern Spain. Sci. Total Environ. 378, 151-155. doi:10.1016/j.scitotenv.2007.01.041

Cerdà, A., Doerr, S.H., 2008. The effect of ash and needle cover on surface runoff and erosion in the immediate post-fire period. Catena 74, 256-263. doi:10.1016/j.catena.2008.03.010

Cerdan, O., Souchere, V., Lecomte, V., Couturier, A., Le Bissonnais, Y., 2002. Incorporating soil surface crusting processes in an expert-based runoff model: Sealing and Transfer by Runoff and Erosion related to Agricultural Management. Catena 46, 189-205. doi:10.1016/S03418162(01)00166-7

Chazelle, B., Lambert, L., Capoccioni, C.P., 2014. Railway vulnerability in case of extremes floods. Knowledge and risk management. Houille Blanche 48-54. doi:10.1051/lhb/2014016

Christensen, F.M., Andersen, O., Duijm, N.J., Harremoës, P., 2003. Risk terminology-a platform for common understanding and better communication. J. Hazard. Mater. 103, 181-203. doi:10.1016/S0304-3894(03)00039-6

Cros-Cayot, S., 1996. Distribution spatiale des transferts de surface à l'échelle du versant. Contexte armoricain. Ecole Nationale Supérieure Agronomique de Rennes.

Dabney, S.M., Yoder, D.C., Vieira, D.A.N., Bingner, R.L., 2011. Enhancing RUSLE to include runoffdriven phenomena. Hydrol. Process. 25, 1373-1390. doi:10.1002/hyp.7897

Daroussin, J., King, D., 1997. A pedotransfer rules database to interpret the soil geographical database of Europe for environmental purposes. Presented at the the workshop on the use of pedotransfer in soil hydrology research in Europe, Orléans, FRA, pp. 25-40.

Defrance, D., 2014. Adaptation and evaluation of a flash flood warning system in ungauged mountainous catchments (Earth Sciences). Université Pierre et Marie Curie - Paris VI.

Dehotin, J., Breil, P., 2011a. Technical report of the IRIP project: mapping the flooding by runoff (Technical report). IRSTEA Hydrology-Hydraulic Research Unit.

Dehotin, J., Breil, P., 2011b. IRIP project: Research bibliographic report on surface runoff mapping (Literature review). IRSTEA Hydrology-Hydraulic Research Unit.

Dehotin, J., Breil, P., Braud, I., de Lavenne, A., Lagouy, M., Sarrazin, B., 2015a. Detecting surface runoff location in a small catchment using distributed and simple observation method. J. Hydrol. 525, 113-129. doi:10.1016/j.jhydrol.2015.02.051 
Dehotin, J., Chazelle, B., Laverne, G., Hasnaoui, A., Lambert, L., Breil, P., Braud, I., 2015b. Applying runoff mapping method IRIP for flooding risk analysis on railway infrastructure. Houille Blanche 56-64. doi:10.1051//hb/20150069

Delahaye, D., Guermond, Y., Langlois, P., 2002. Spatial interaction in the run-off process. Cybergeo Eur. J. Geogr. doi:10.4000/cybergeo.3795

Departmental Directorate of Seine-Maritime, 2013a. Flood Risk Prevention Plan - Presentation report.

Departmental Directorate of Seine-Maritime, 2013b. Flood Risk Prevention Plan of the Lezarde Catchment - Application rules.

DeRoo, A.P.J., Wesseling, C.G., Ritsema, C.J., 1996. LISEM: A single-event physically based hydrological and soil erosion model for drainage basins .1. Theory, input and output. Hydrol. Process. 10, 1107-1117. doi:10.1002/(SICI)1099-1085(199608)10:8<1107::AIDHYP415>3.0.CO;2-4

Douvinet, J., 2008. Les bassins versants sensibles aux « crues rapides » dans le Bassin Parisien Analyse de la structure et de la dynamique de systèmes spatiaux complexes. Université de Caen/Basse-Normandie.

Douvinet, J., Delahaye, D., Langlois, P., 2008. Modélisation de la dynamique potentielle d'un bassin versant et mesure de son efficacité structurelle. Cybergeo Eur. J. Geogr. doi:10.4000/cybergeo.16103

Douvinet, J., Wiel, M.J.V.D., Delahaye, D., Cossart, E., 2014. A flash flood hazard assessment in dry valleys (northern France) by cellular automata modelling. Nat. Hazards 75, 2905-2929. doi:10.1007/s11069-014-1470-3

Dupuis, J., 1969. La carte pédologique de la France au millionième. Rev. Géographie Alp. 219-219.

Faulkner, H., Boardman, J., Ruiz, J.-L., 2010. A simple validated GIS expert system to map relative soil vulnerability and patterns of erosion during the muddy floods of 2000-2001 on the South Downs, Sussex, UK. Land Degrad. Dev. 21, 310-321. doi:10.1002/Idr.1005

Galevski, M., 1955. La corrélation entre les pluies torrentielles et l'intensité de l'érosion (Field observation report).

Gouvazé, J., SMBV, 2013. Floods of 13 \& 14 October 2013: feedback on this unusual weather event. Gravelius, H., 1914. Grundriss der gesamten Gewässerkunde: in vier Bänden. 1. Flusskunde, Compendium of Hydrology, vol. 1: Rivers. Göschen, Berlin, Germany.

Guillobez, S., Lompo, F., De Noni, G., 2000. Le suivi de l'érosion pluviale et hydrique au Burkina Faso. Utilisation d'un modèle cartographique. Sci. Chang. Planétaires Sécher. 11, 163-9.

Hagen-Zanker, A., 2009. An improved Fuzzy Kappa statistic that accounts for spatial autocorrelation. Int. J. Geogr. Inf. Sci. 23, 61-73. doi:10.1080/13658810802570317

Hargrove, W.W., Hoffman, F.M., Hessburg, P.F., 2006. Mapcurves: a quantitative method for comparing categorical maps. J. Geogr. Syst. 8, 187-208. doi:10.1007/s10109-006-0025-x

Hauchard, E., 2002. Risk Prevention Plan for floods and surface runoff. Methodol. Defin. Surf. Runoff Hazard Hydrogeomorphological Approach Dep. Equip. Dir. 76.

Hauchard, E., Delahaye, D., Freiré-Diaz, S., 2002. Fractal organization of the soil occupation: consequences on the runoff and gully erosion in arable cropping areas. Géomorphologie Relief Process. Environ. 8, 181-196.

Hauchard, E., Laignel, B., 2008. Morphotectonic evolution of the north-western margin of the Paris Basin. Z. Für Geomorphol. 52, 463-488. doi:10.1127/0372-8854/2008/0052-0463

Hewlett, J.D., 1982. Principles of forest hydrology. University of Georgia Press.

Hewlett, J.D., Hibbert, A.R., 1967. Factors affecting the response of small watersheds to precipitation in humid areas. For. Hydrol. 275-290.

Hogan, R.J., Mason, I.B., 2012. Deterministic forecasts of binary events. Forecast Verification Pract. Guide Atmospheric Sci. Second Ed. 31-59. doi:10.1002/9781119960003.ch3

Holzmann, H., Sereinig, N., 1997. In situ measurements of hillslope runoff components with different types of forest vegetation. IAHS PRESS WALLINGFORD ENGL 317-324. 
Horton, R.E., 1933. The role of infiltration in the hydrologic cycle. Trans. Am. Geophys. Union 14, 446-460. doi:10.1029/TR014i001p00446

Horton, R.E., 1932. Drainage-basin characteristics. Trans. Am. Geophys. Union 13, 350. doi:10.1029/TR013i001p00350

Hudson, N., 1993. Field measurement of soil erosion and runoff. Food \& Agriculture Org.

IPCC, 2003. IPCC Third Assessment Report - Climate Change 2001: 2.3.2.1 Palaeoclimate proxy indicators.

Jamagne, M., Hardy, R., King, D., Bornand, M., 1995. La base de données géographique des sols de France. Etude Gest. Sols 2, 153-172.

Javelle, P., Demargne, J., Defrance, D., Pansu, J., Arnaud, P., 2014. Evaluating flash-flood warnings at ungauged locations using post-event surveys: a case study with the AIGA warning system. Hydrol. Sci. J. 59, 1390-1402. doi:10.1080/02626667.2014.923970

Laflen, J., Lane, L., Foster, G., 1991. Wepp - a New Generation of Erosion Prediction Technology. J. Soil Water Conserv. 46, 34-38.

Langlois, P., Delahaye, D., 2002. RuiCells, automate cellulaire pour la simulation du ruissellement de surface. Rev. Int. Géomat. 12, 461-487.

Laverne, G., 2013. Application and validation of a runoff areas mapping tool in the railway context: identification of sites subject to flooding by runoff (Master thesis). IRSTEA HydrologyHydraulic Research Unit.

Le Bissonnais, Y., Montier, C., Jamagne, M., Daroussin, J., King, D., 2002. Mapping erosion risk for cultivated soil in France. Catena 46, 207-220. doi:10.1016/S0341-8162(01)00167-9

Le Gouee, P., Delahaye, D., Bermond, M., Marie, M., Douvinet, J., Viel, V., 2010. SCALES: a large-scale assessment model of soil erosion hazard in Basse-Normandie (northern-western France). Earth Surf. Process. Landf. 35, 887-901. doi:10.1002/esp.1942

Legros, J., 2014. Study of datas gived by a method of flooding harzard by surface runoff in flow discharge modelling linked with this kind of flooding (Master thesis). IRSTEA HydrologyHydraulic Research Unit.

MacQueen, J., 1967. Some methods for classification and analysis of multivariate observations. Presented at the the fifth Berkeley symposium on mathematical statistics and probability, Oakland, CA, USA., pp. 281-297.

Moriasi, D.N., Arnold, J.G., Van Liew, M.W., Bingner, R.L., Harmel, R.D., Veith, T.L., 2007. Model evaluation guidelines for systematic quantification of accuracy in watershed simulations. Trans. Asabe 50, 885-900. doi:10.13031/2013.23153

Naulin, J.-P., Payrastre, O., Gaume, E., 2013. Spatially distributed flood forecasting in flash flood prone areas: Application to road network supervision in Southern France. J. Hydrol. 486, 8899. doi:10.1016/j.jhydrol.2013.01.044

Nearing, M.A., Foster, G.R., Lane, L.J., Finkner, S.C., 1989. Erosion Prediction Project Technology.

Onda, Y., Komatsu, Y., Tsujimura, M., Fujihara, J., 2001. The role of subsurface runoff through bedrock on storm flow generation. Hydrol. Process. 15, 1693-1706. doi:10.1002/hyp.234

Ortega, K.L., Smith, T.M., Manross, K.L., Kolodziej, A.G., Scharfenberg, K.A., Witt, A., Gourley, J.J., 2009. The severe hazards analysis and verification experiment. Bull. Am. Meteorol. Soc. 90, 1519-1530.

Pams-Capoccioni, C., Nivon, D., Amblard, J., De cesare, G., Ghilardi, T., 2015. Risk analysis for railway traffic of overflowing of the drainage system on High Speed Lines. Houille Blanche 39-45. doi:10.1051/lhb/20150044

Piney, S., 2009. Etude bibliographique de trois méthodologies appliquées au risque érosion: synthèse et perspective en vue d'une cartographie départementale du risque de ruissellement.

Pons, F., Delgado, J.-L., Guero, P., Berthier, E., Kerloc'h, B., Piney, S., Felts, D., 2010. A method for the assessment of the flood risk related to direct runoff and flash floods. SimHydro 2010 Sophia Antipolis.

Reuter, H.I., Wendroth, O., Kersebaum, K.C., 2006. Optimisation of relief classification for different levels of generalisation. Geomorphology 77, 79-89. doi:10.1016/j.geomorph.2006.01.001 
Robinson, D.A., Phillips, C.P., 2001. Crust development in relation to vegetation and agricultural practice on erosion susceptible, dispersive clay soils from central and southern Italy. Soil Tillage Res. 60, 1-9. doi:10.1016/S0167-1987(01)00166-0

Schmocker-Fackel, P., Naef, F., Scherrer, S., 2007. Identifying runoff processes on the plot and catchment scale. Hydrol. Earth Syst. Sci. 11, 891-906. doi:10.5194/hess-11-891-2007

Schumm, S.A., 1956. Evolution of drainage systems and slopes in badlands at Perth Amboy, New Jersey. Geol. Soc. Am. Bull. 67, 597-646. doi:10.1130/00167606(1956)67[597:EODSAS]2.0.CO;2

Smith, R.E., Goodrich, D.C., Woolhiser, D.A., Unkrich, C.L., 1995. KINEROS-A kinematic runoff and erosion model. Comput. Models Watershed Hydrol. 20, 627-668.

Stanski, H.R., Wilson, L.J., Burrows, W.R., 1989. Survey of common verification methods in meteorology. World Meteorological Organization Geneva.

Tetzlaff, D., Soulsby, C., Waldron, S., Malcolm, I.A., Bacon, P.J., Dunn, S.M., Lilly, A., Youngson, A.F., 2007. Conceptualization of runoff processes using a geographical information system and tracers in a nested mesoscale catchment. Hydrol. Process. 21, 1289-1307. doi:10.1002/hyp.6309

Thywissen, K., 2006. Components of risk: a comparative glossary. UNU- EHS.

UNDHA, 1992. Internationally agreed glossary of basic terms related to disaster management. UN DHA U. N. Dep. Humanit. Aff. Geneva.

UNDRO, 1979. Natural disasters and vulnerability analysis : report of Expert Group Meeting (No. naturaldisasters00offi). Geneva.

Versini, P.-A., Gaume, E., Andrieu, H., 2010a. Assessment of the susceptibility of roads to flooding based on geographical information - test in a flash flood prone area (the Gard region, France). Nat. Hazards Earth Syst. Sci. 10, 793-803. doi:/10/793/2010/

Versini, P.-A., Gaume, E., Andrieu, H., 2010b. Application of a distributed hydrological model to the design of a road inundation warning system for flash flood prone areas. Nat. Hazards Earth Syst. Sci. 10, 805-817. doi:/10/805/2010/

Wischmeier, W.H., 1959. A Rainfall Erosion Index for a Universal Soil-Loss Equation. Soil Sci. Soc. Am. J. 23, 246. doi:10.2136/sssaj1959.03615995002300030027x 


\section{Figure captions:}

Figure 1: Scheme of the IRIP method to create the three susceptibility maps of surface runoff generation, transfer, and accumulation, with the input data

Figure 2: Description of the Lézarde catchment which is located in the Seine-Maritime County and which ranges from 1 to 138 meters of elevation with a short permanent hydrographic network

Figure 3: Description of the rainfall event of October 13, 2013 that impacted the northern part of the Lézarde catchment

Figure 4: Explanative schemes of the data formatting for the comparison with the impact databases, a) Process to detect pixel persistence and remove isolated pixels, b) presentation of the surfaces taken into account for the computation of the contingency table.

Figure 5: The IRIP map of susceptibility of the Lézarde catchment to surface runoff generation

Figure 6: The IRIP map of susceptibility of the Lézarde catchment to surface runoff transfer

Figure 7: The IRIP map of susceptibility of the Lézarde catchment to surface runoff accumulation

Figure 8: Superimposition of the high susceptibility levels of the IRIP map of accumulation and of the surface runoff regulatory zoning

Figure 9: Superimposition of the high susceptibility levels of the IRIP map of transfer and of the soil erosion regulatory zoning

Figure 10: Superimposition of the high susceptibility levels of the IRIP map of transfer and accumulation after processing and of the road network of the three sub-catchments impacted by the rainfall event, along with the road sections impacted by surface runoff and the hydraulic structure locations

Figure 11: Superimposition of the high susceptibility levels of the IRIP map of transfer and accumulation and of the soil erosion regulatory zoning

Figure 12: Photos from Google Street View illustrating the environment configuration around four impacted road sections in order to explain the reason of the IRIP false alarms

Table 1: List of the 5 indictors per map used to create the 3 IRIP maps of generation, transfer, and accumulation susceptibility, with the criteria of favourability for each indicator

Table 2: The theoretical contingency table to analyze the correlation between the IRIP maps and the comparison data 
Table 3: The five verification indicators computed to analyze the correlation between the IRIP maps and the comparison data

Table 4: Result summary of the comparison between the regulatory zonings and the high susceptibility levels of the IRIP maps of transfer and accumulation, using buffer area sizes of 0,25 and 50 meters

Table 5: Result summary of the comparison between the impact locations on the transportation network and the high susceptibility level locations on the IRIP maps of transfer and accumulation, using buffer area sizes of 25 and 50 meters 

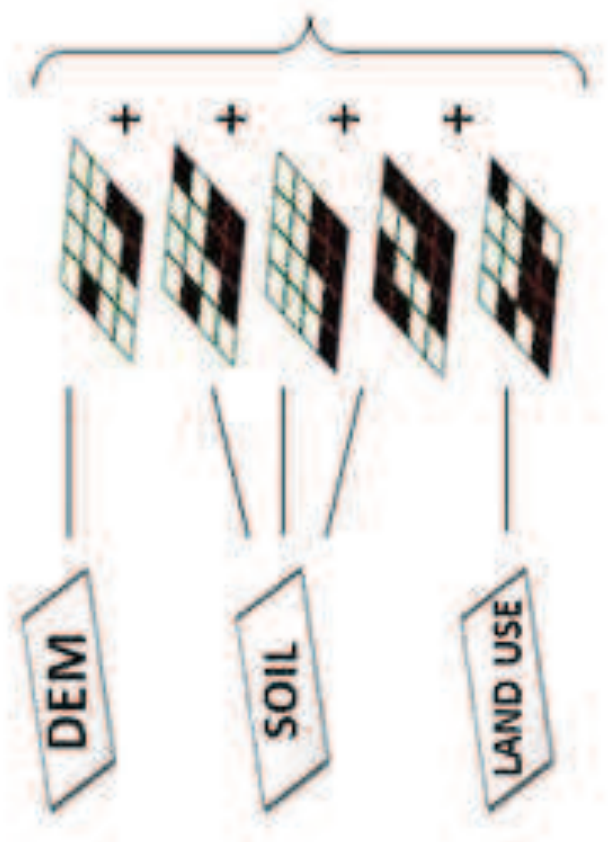

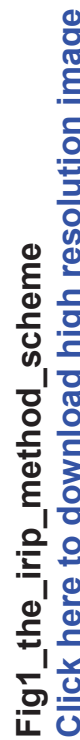
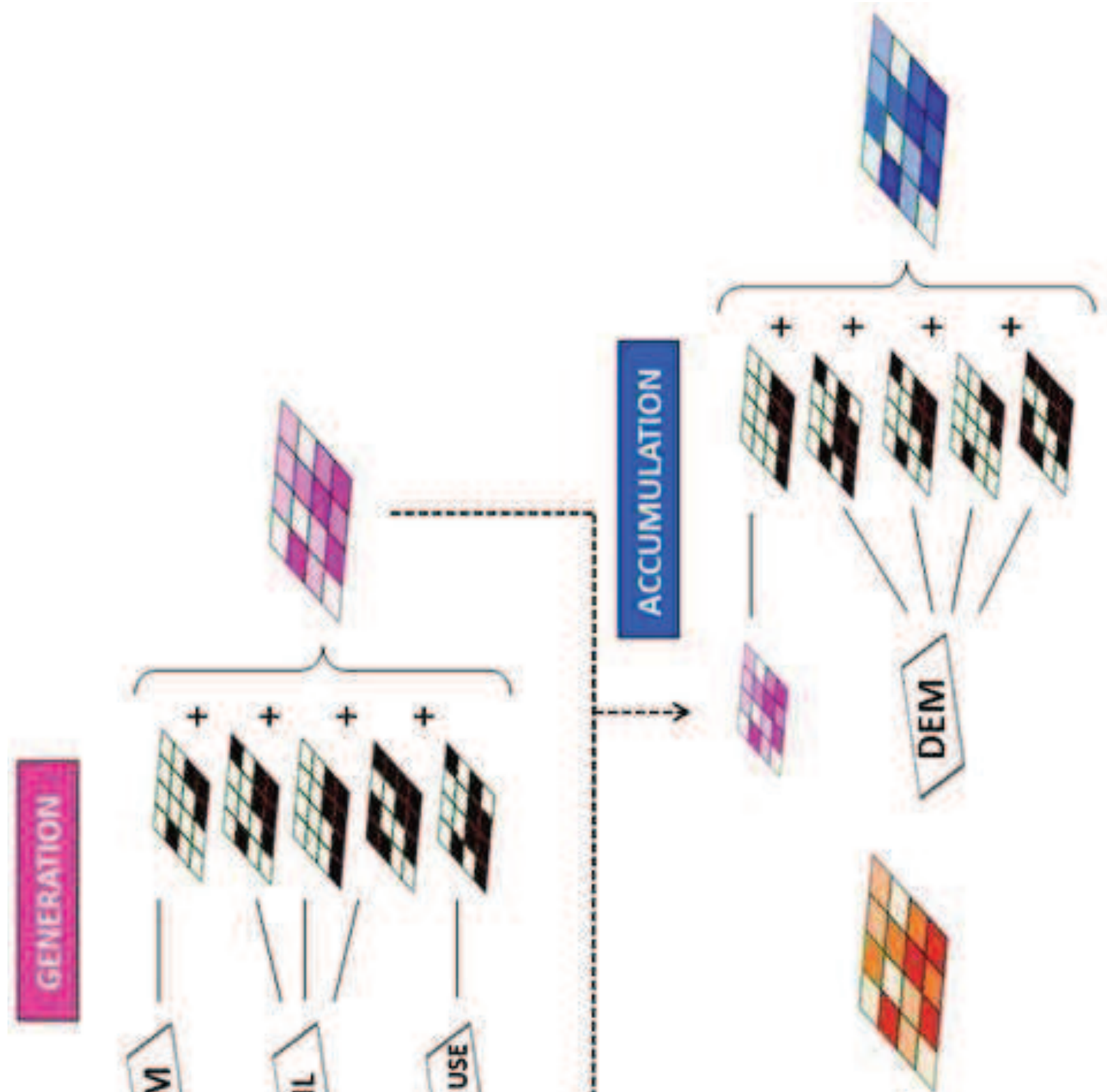


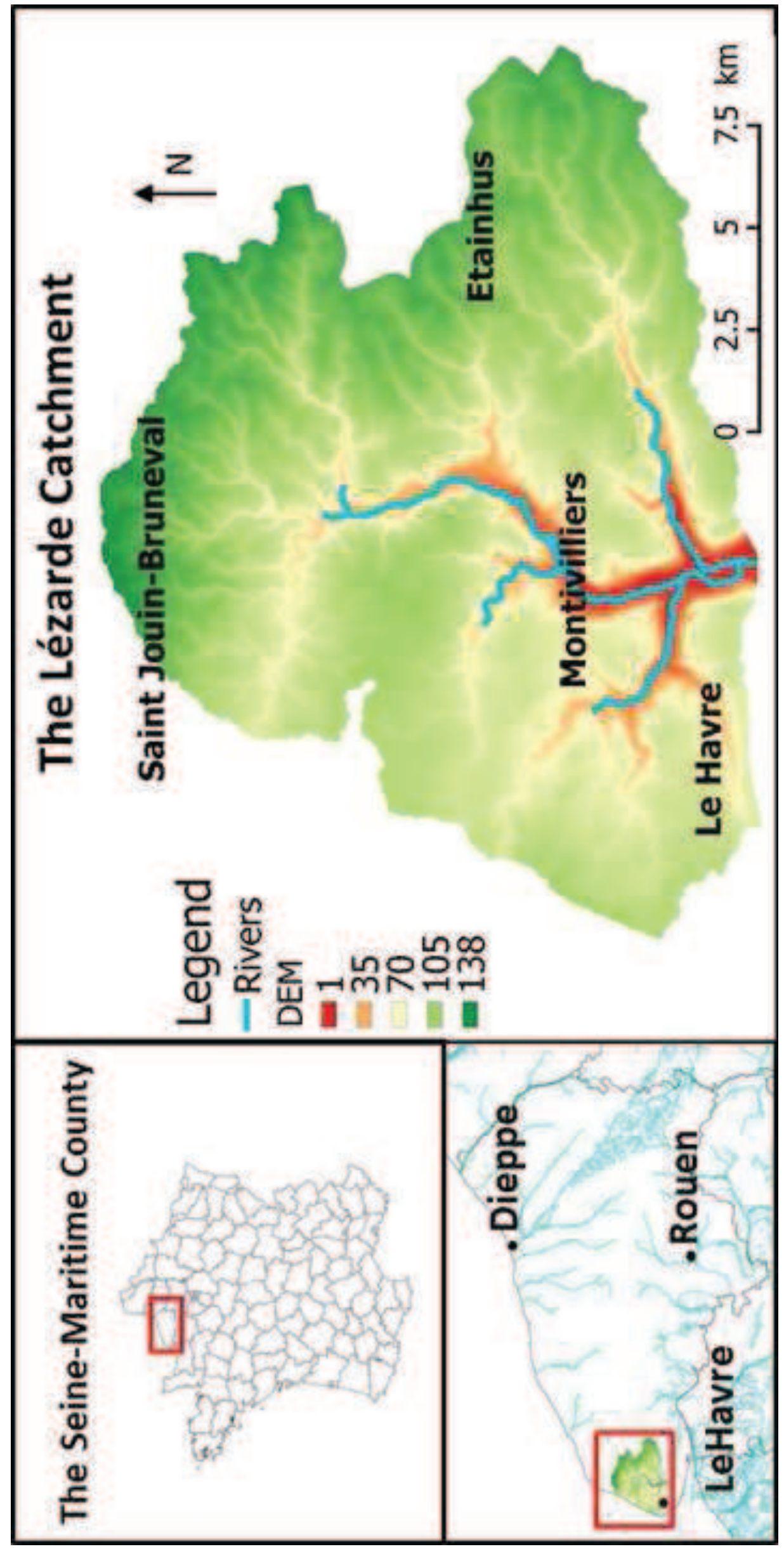




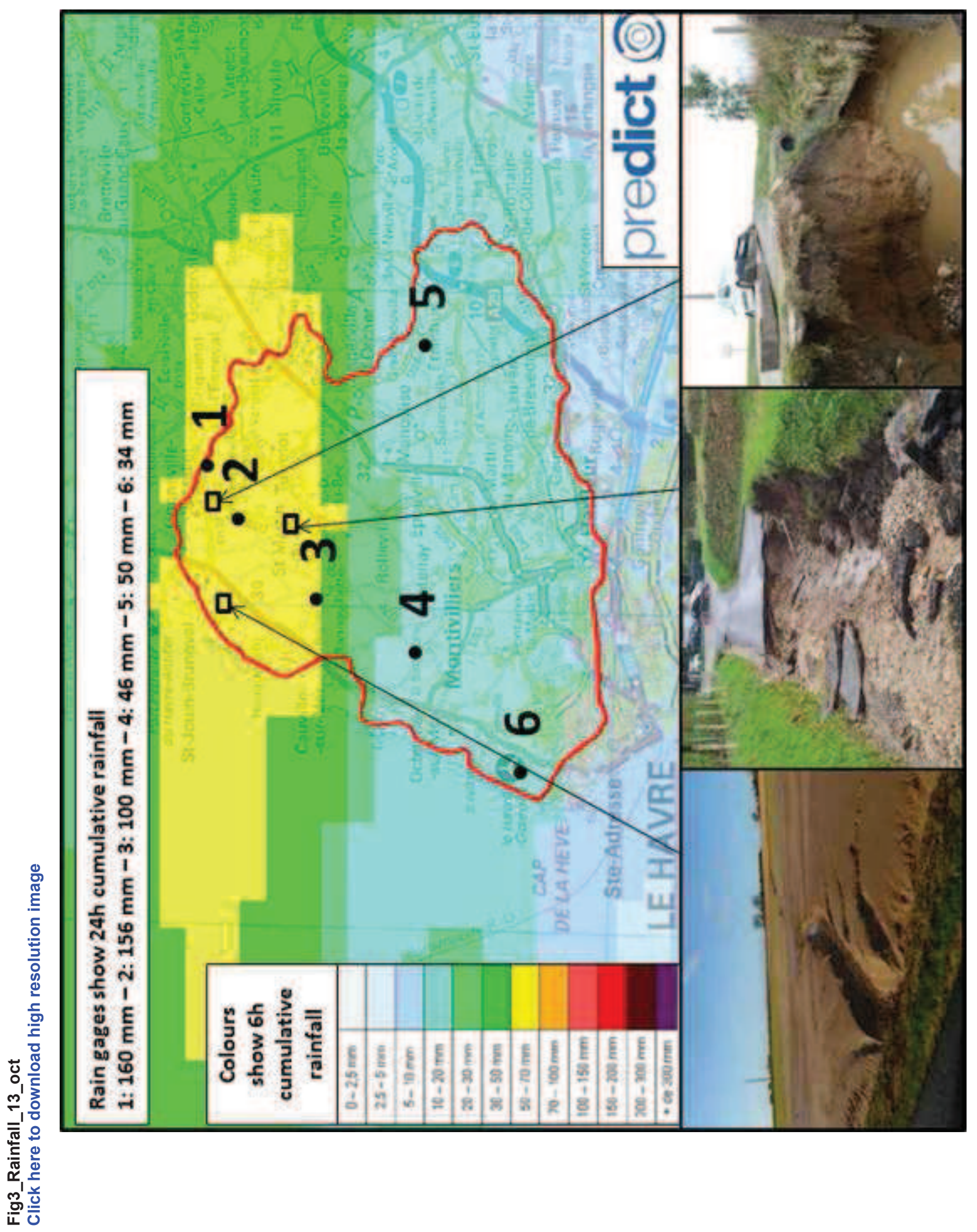




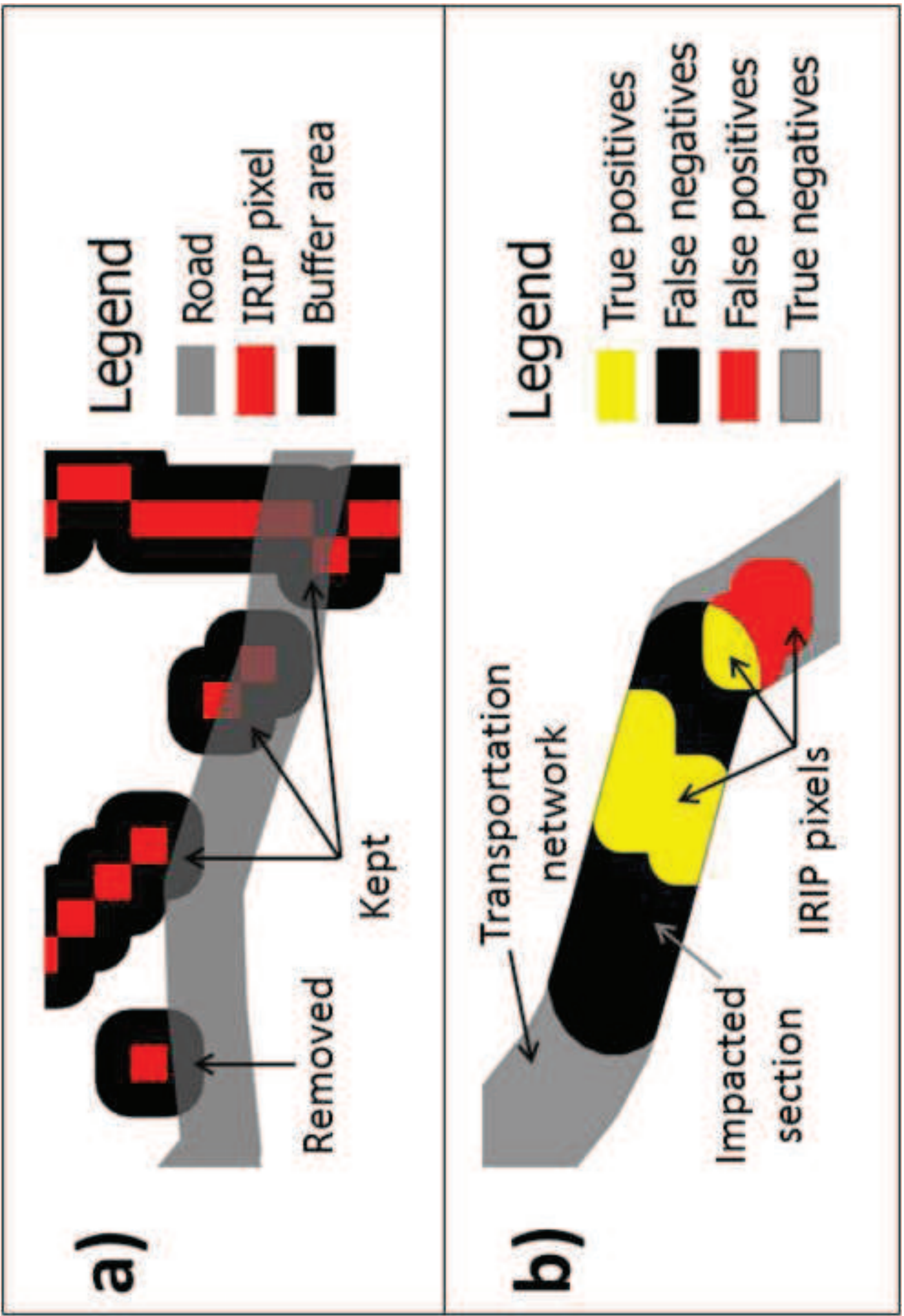

은 


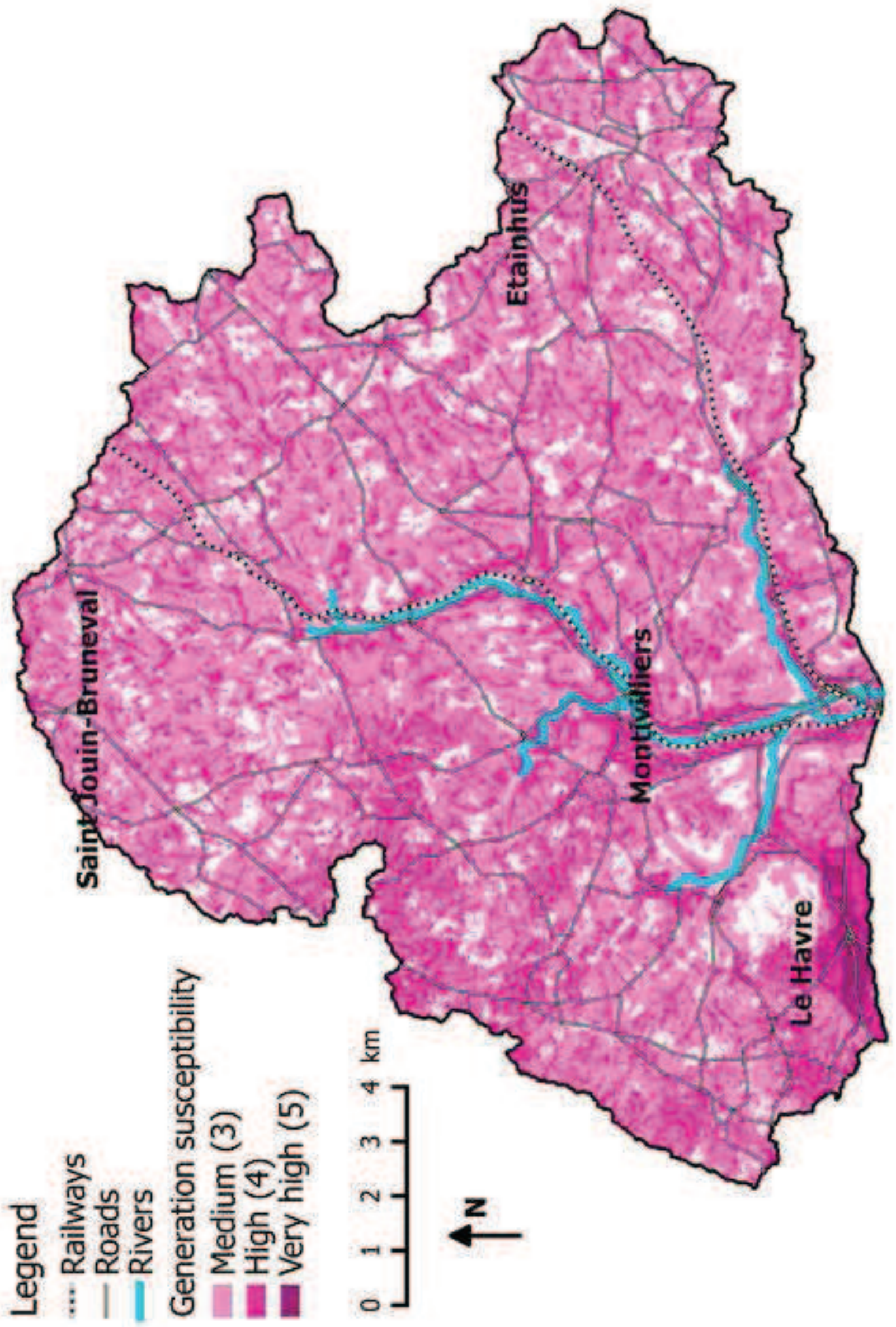


Author-produced version of the article published in Journal of Hydrology, Volume 541, Part A, October 2016, Pages 495-509 The original publication is available at http://www.sciencedirect.com/ doi : 10.1016/.j.jhydrol.2016.05.049

(C. This manuscript version is made available under the CC-BY-NC-ND 4.0 license

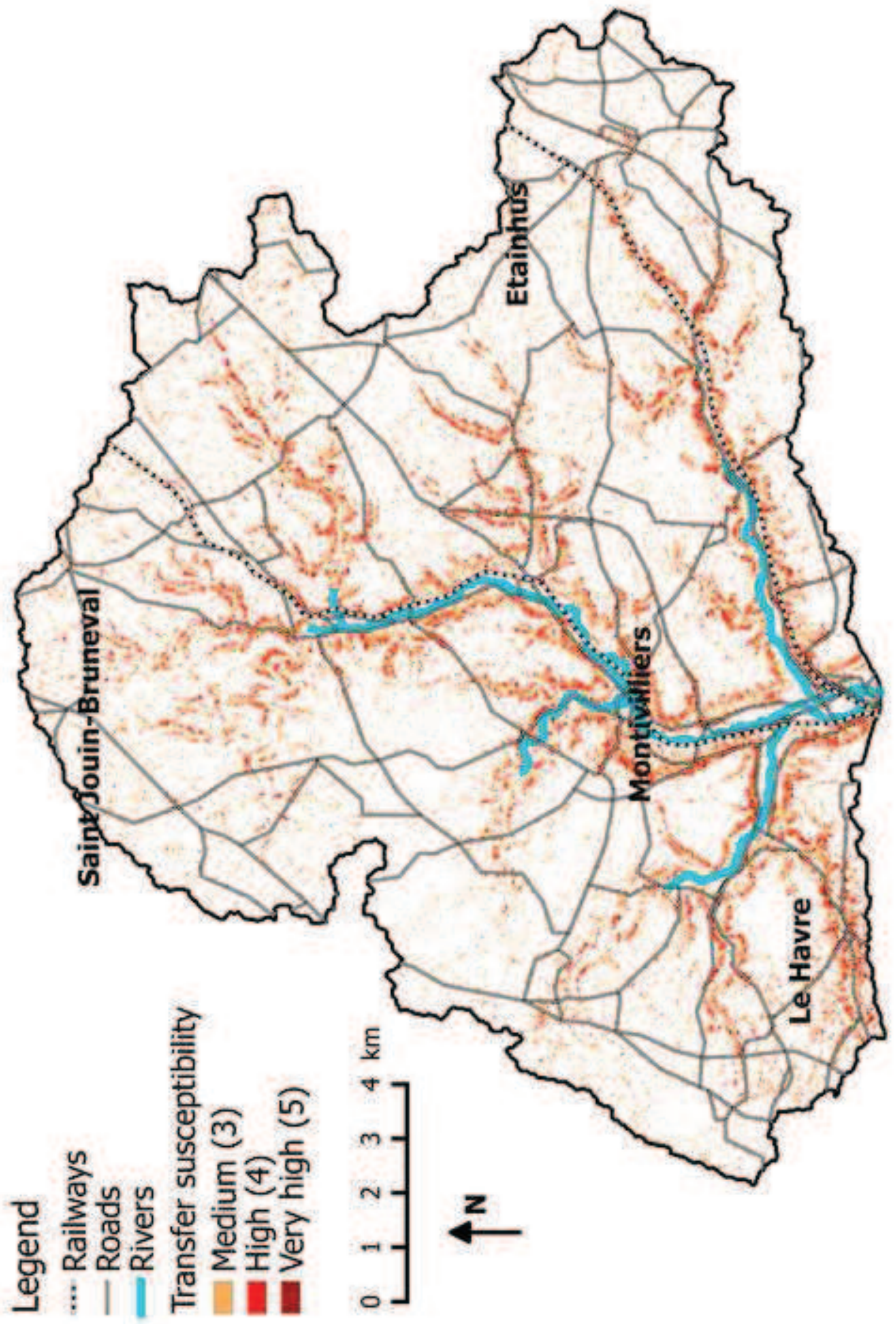


Author-produced version of the article published in Journal of Hydrology, Volume 541, Part A, October 2016, Pages 495-509 The original publication is available at http://www.sciencedirect.com/ doi : 10.1016/.j.jhydrol.2016.05.049 (C. This manuscript version is made available under the CC-BY-NC-ND 4.0 license

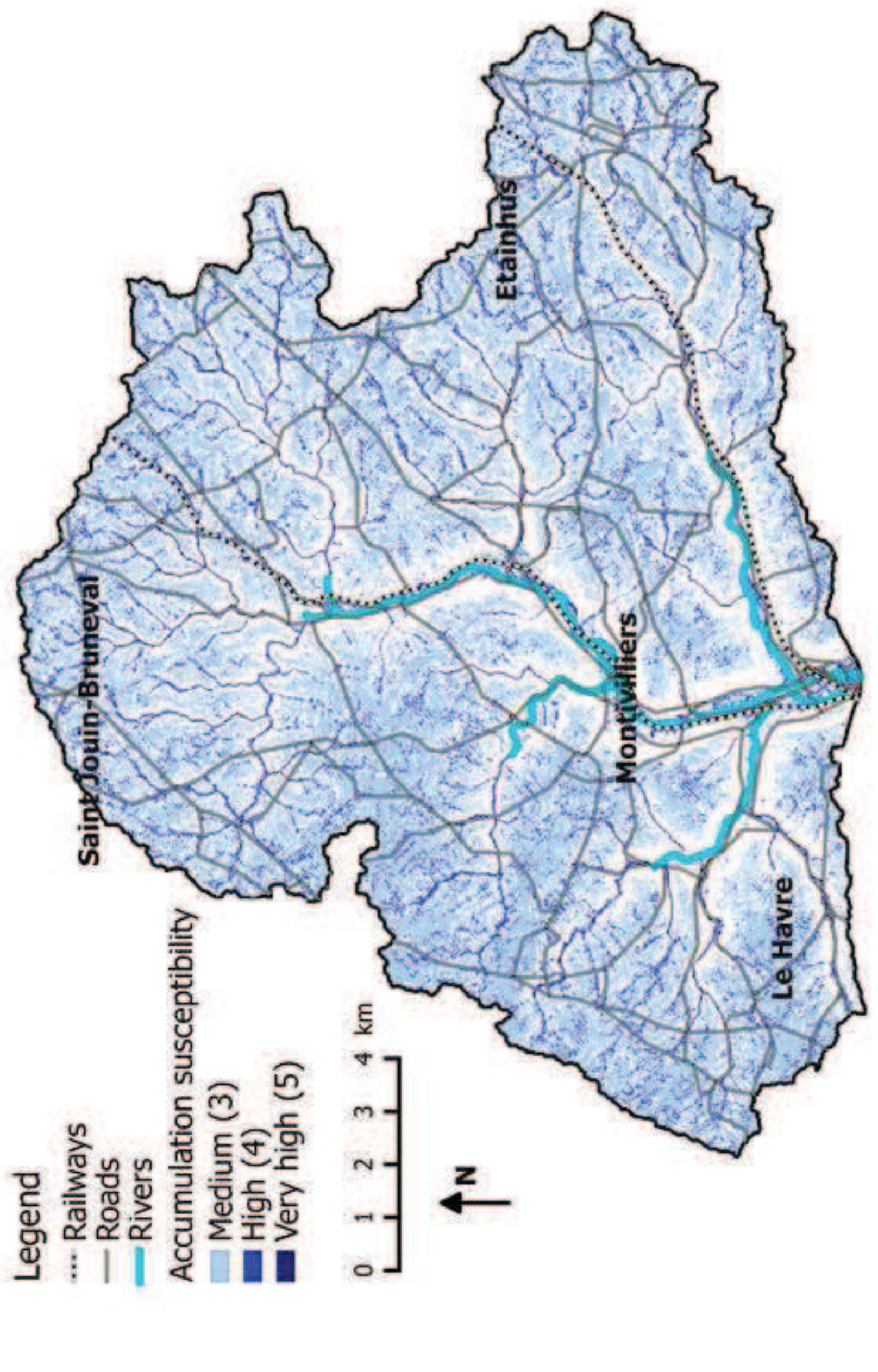




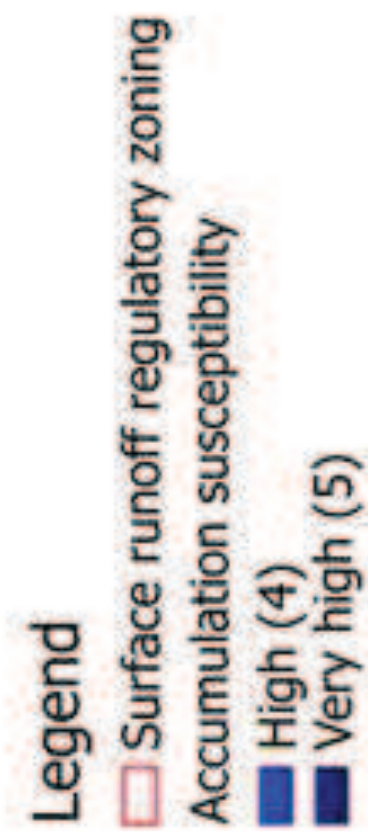

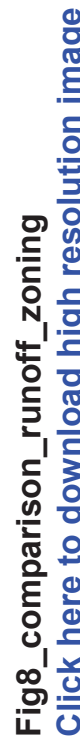

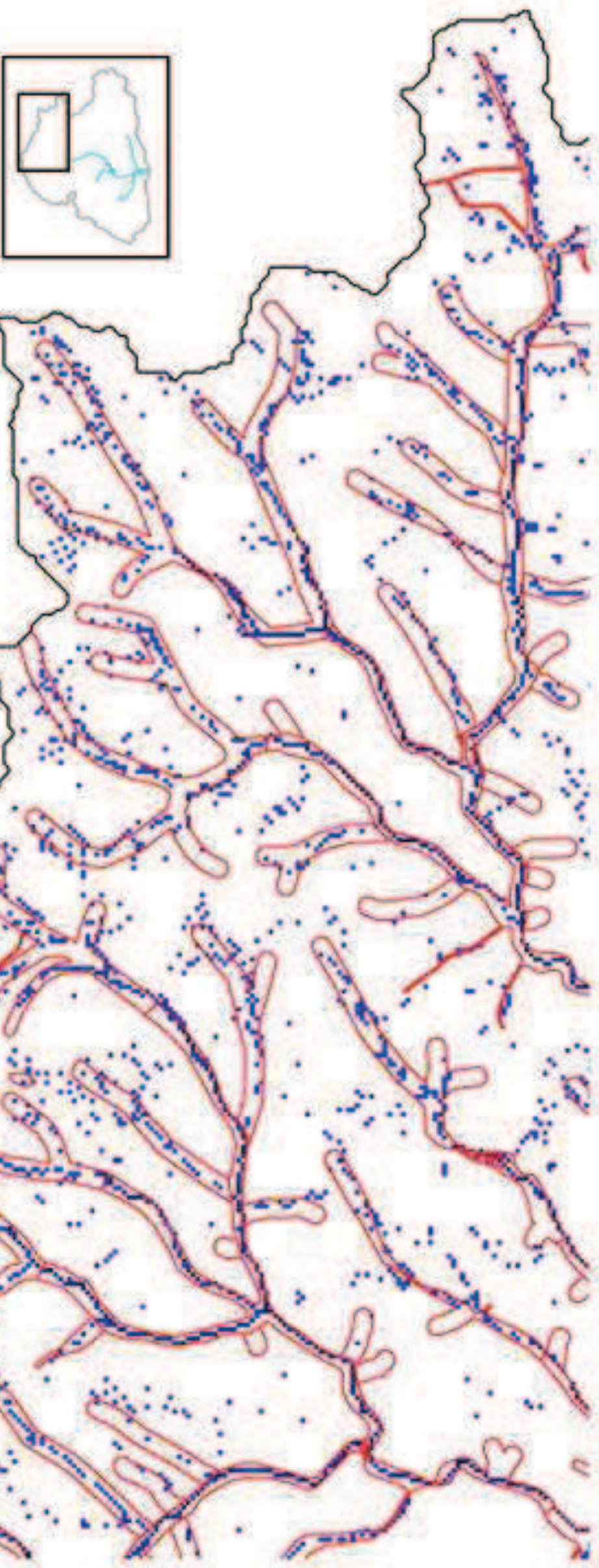




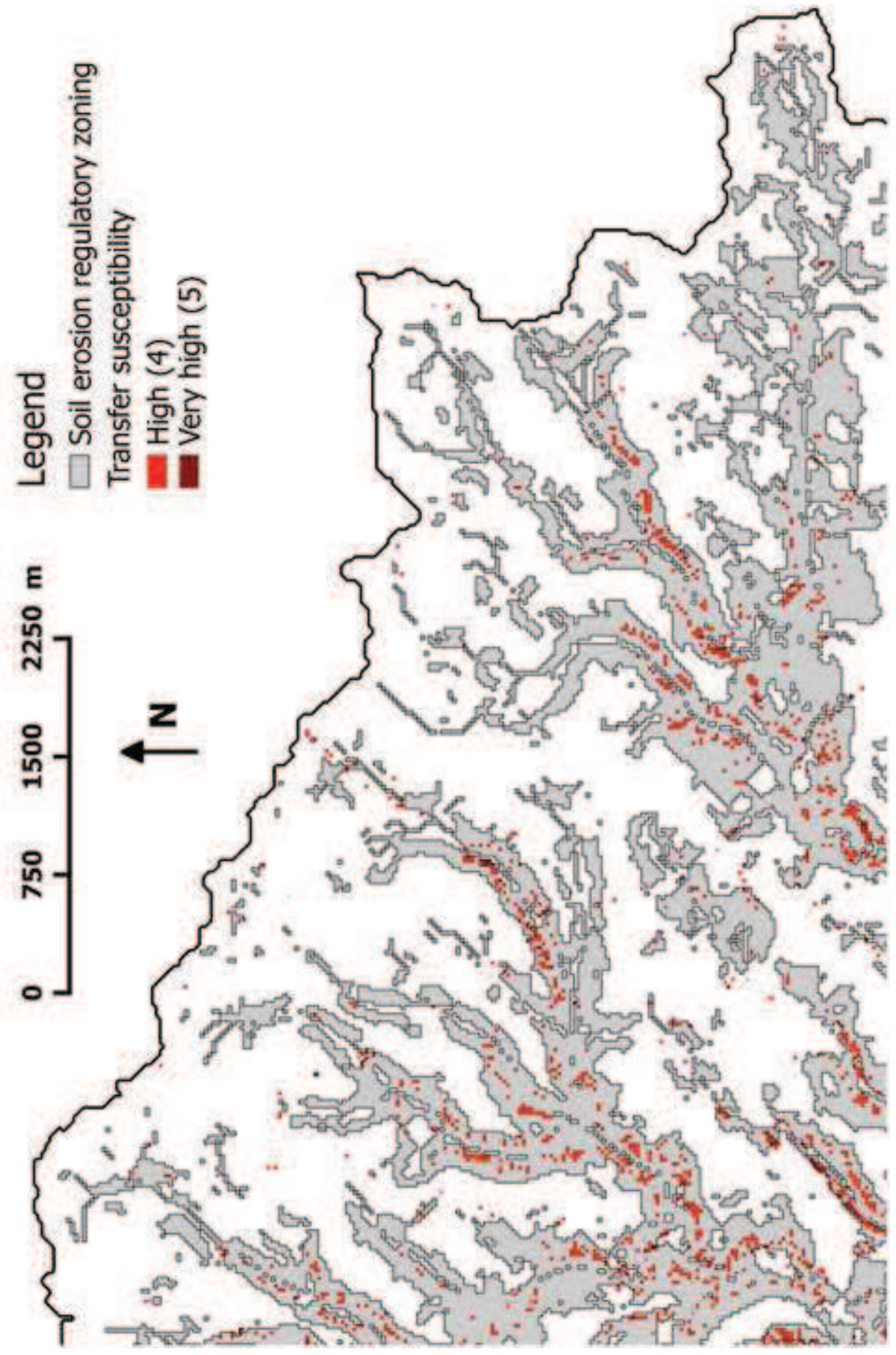


Author-produced version of the article published in Journal of Hydrology, Volume 541, Part A, October 2016, Pages 495-509 The original publication is available at http://www.sciencedirect.com/ doi : 10.1016/j.jhydrol.2016.05.049

(C. This manuscript version is made available under the CC-BY-NC-ND 4.0 license

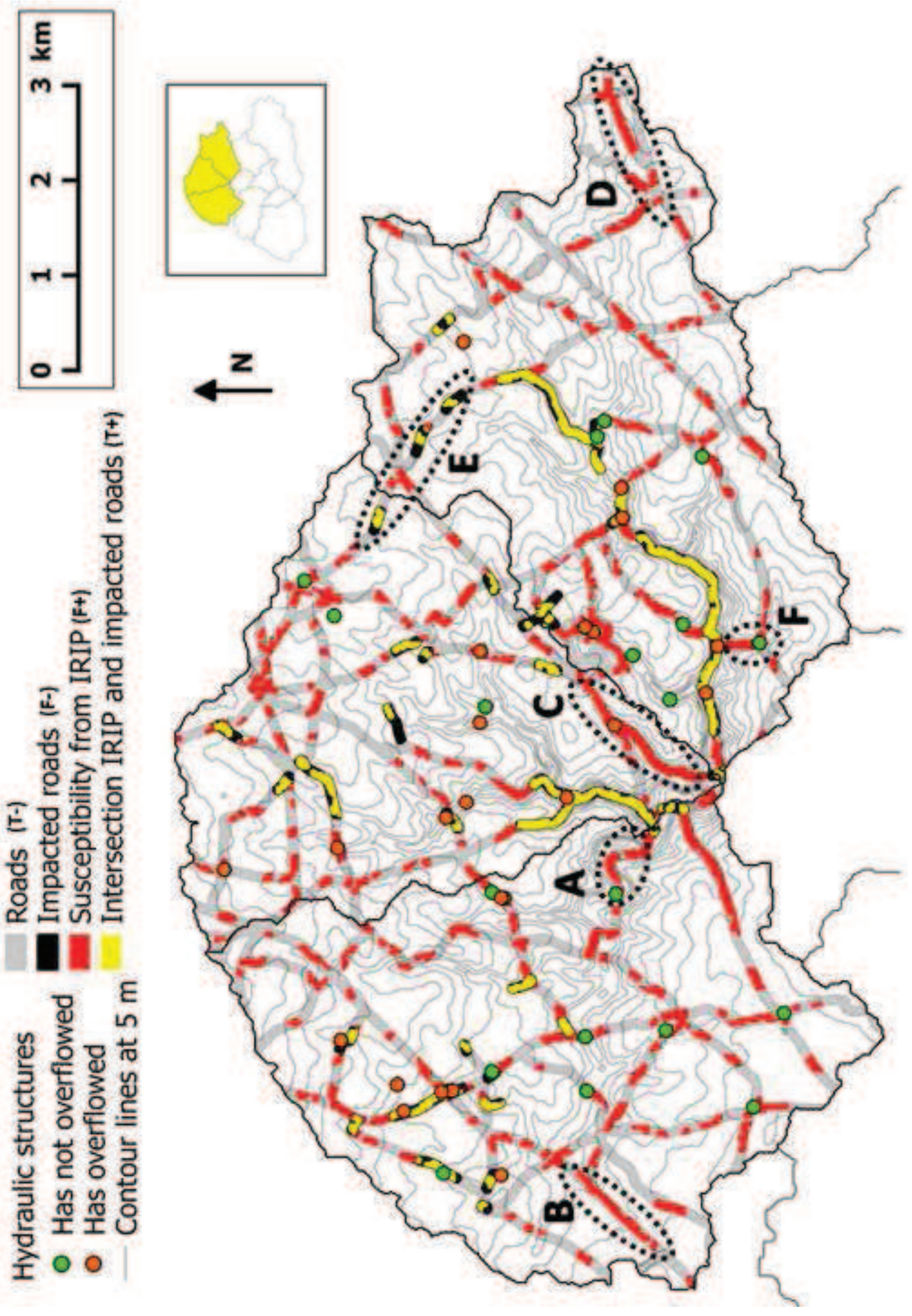



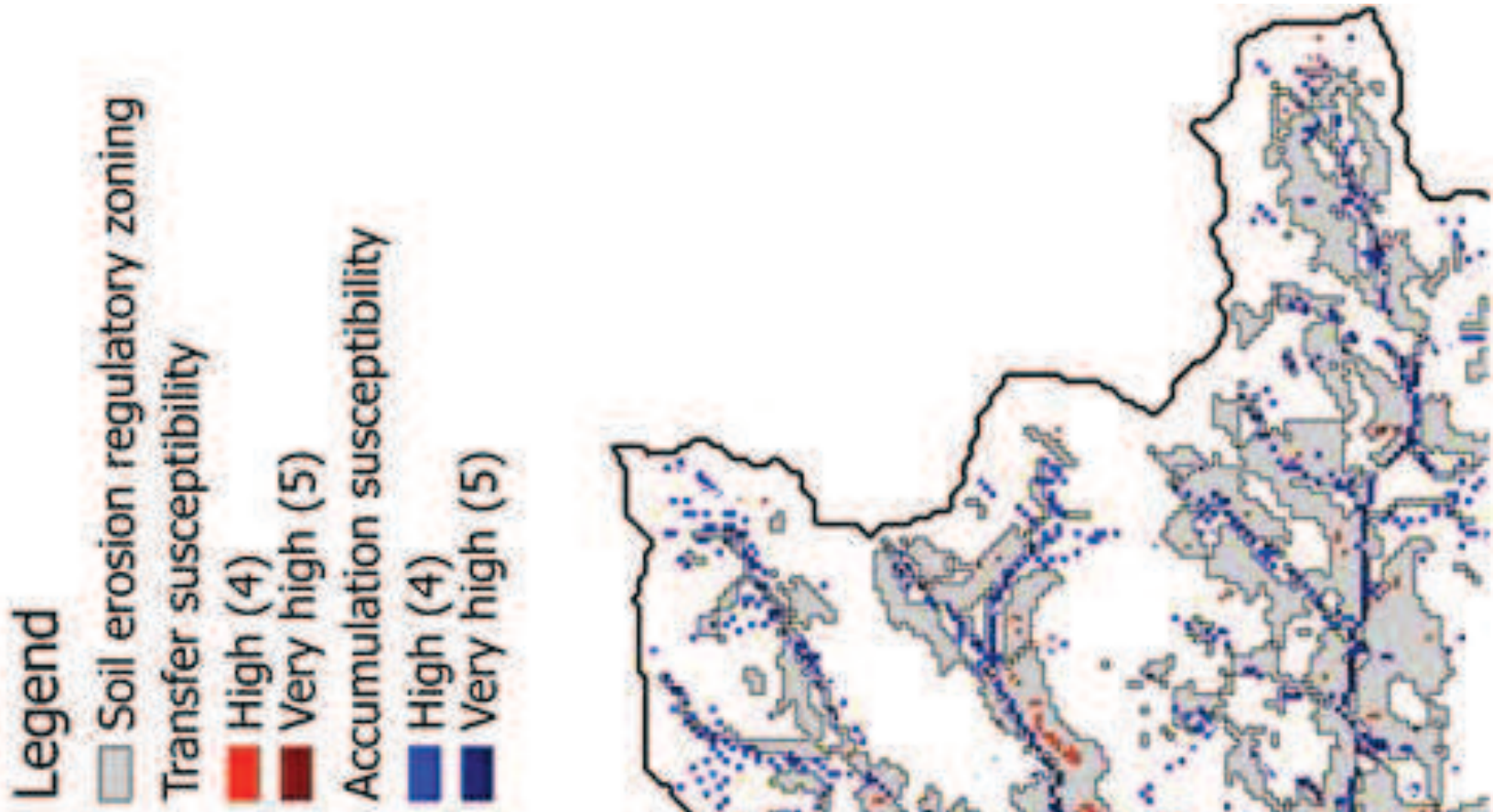

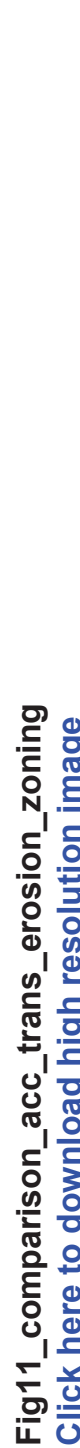

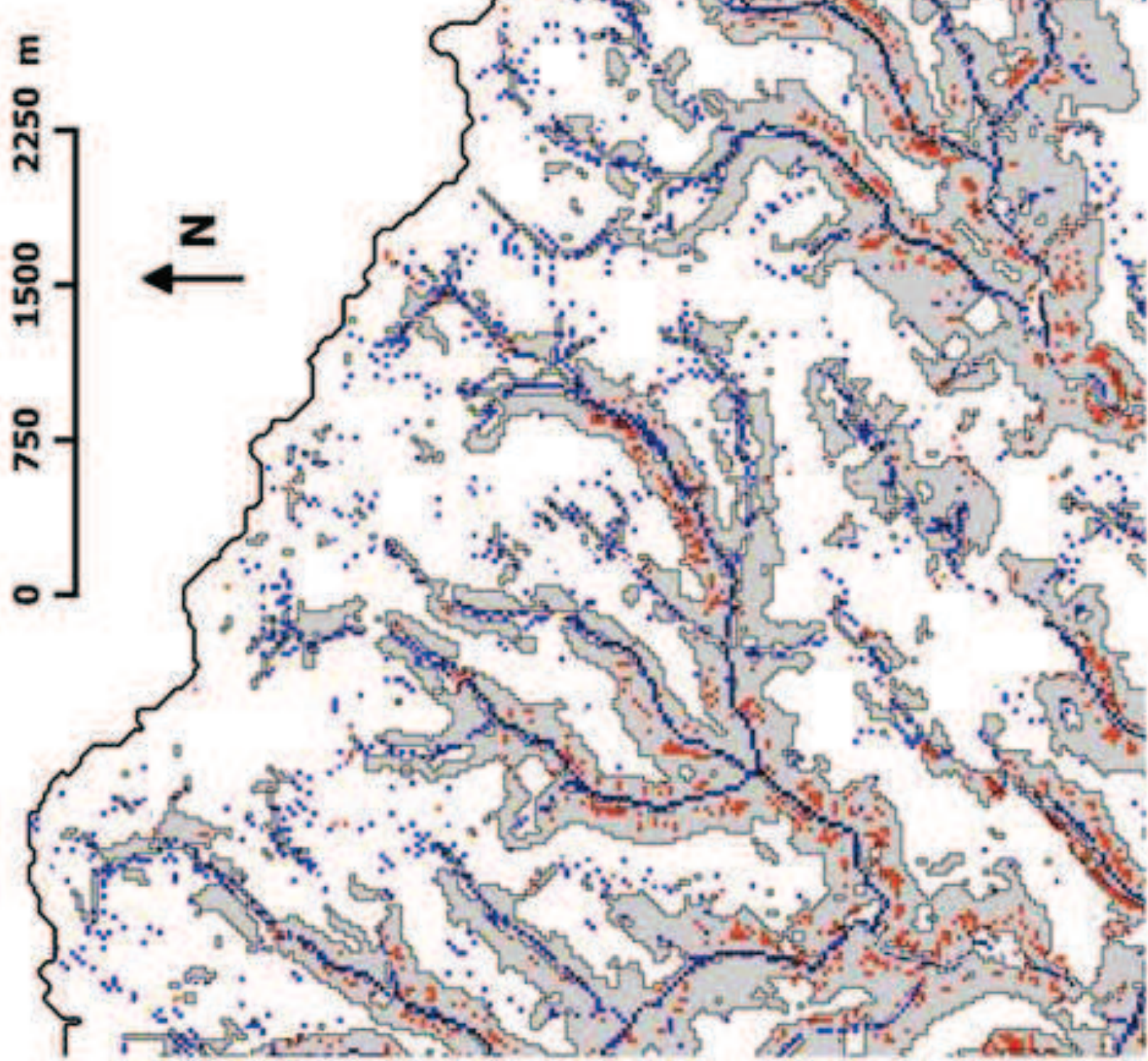




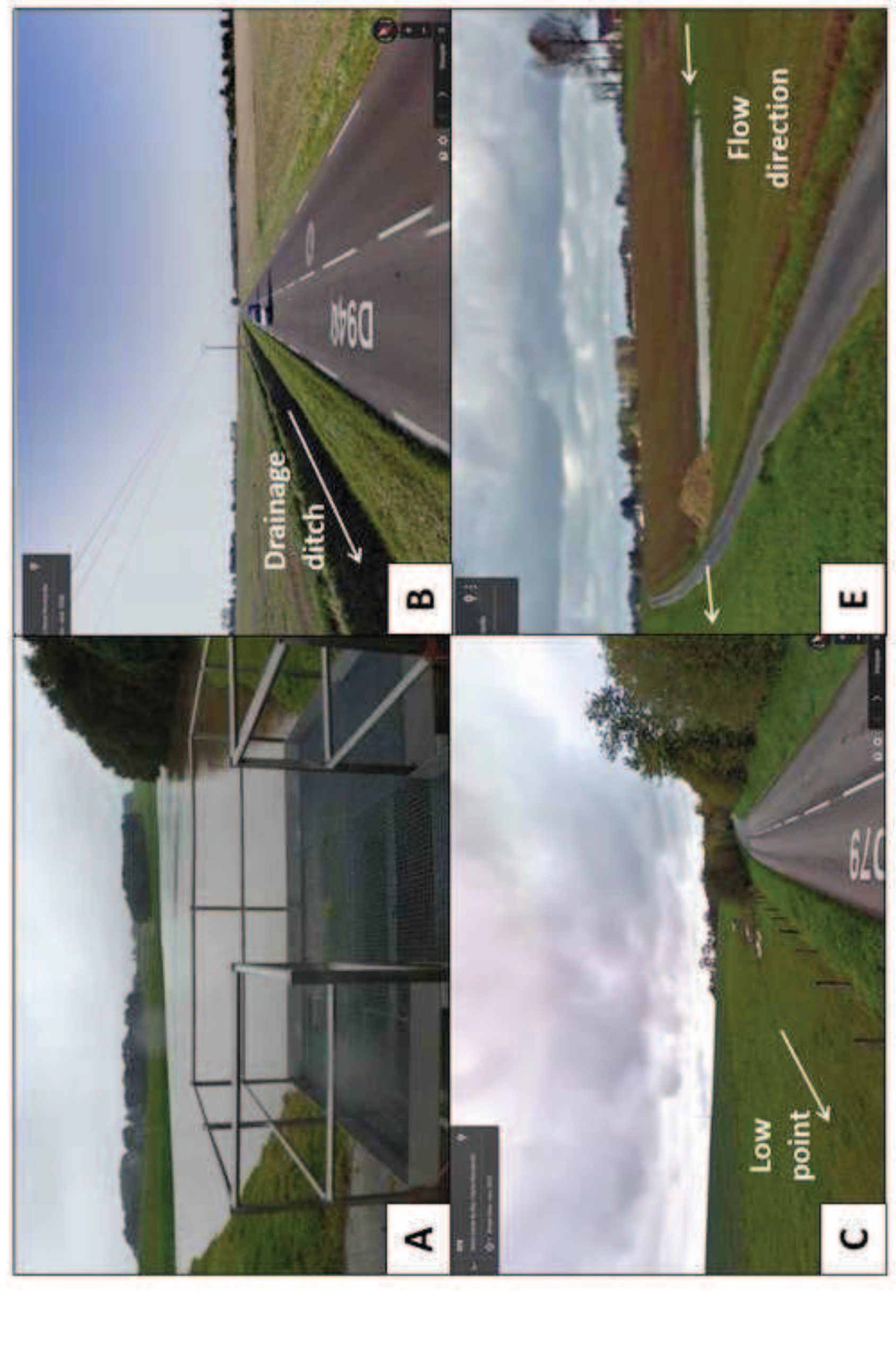




\begin{tabular}{|c|c|c|}
\hline IRIP maps & Indicators & Values \\
\hline \multirow{10}{*}{ Generation } & \multirow{2}{*}{ Soil permeability } & 0: High permeability \\
\hline & & 1: Low permeability \\
\hline & \multirow{2}{*}{ Soil thickness } & 0: Thick soil \\
\hline & & 1: Thin soil \\
\hline & \multirow{2}{*}{ Soil erodibility } & 0: Low erodibility \\
\hline & & 1: High erodibility \\
\hline & \multirow{2}{*}{ Topography } & 0: Slope $<\mathrm{t}_{1}$ AND topographic index $<\mathrm{t}_{2}$ \\
\hline & & 1: Slope $>t_{1}$ OR topographic index $>t_{2}$ \\
\hline & \multirow{2}{*}{ Land use } & 0: Infiltrative surfaces \\
\hline & & 1: Impervious surfaces \\
\hline \multirow{10}{*}{ Transfer } & \multirow{2}{*}{$\begin{array}{c}\text { Upstream generation } \\
\text { susceptibility }\end{array}$} & 0: Low upstream generation susceptibility \\
\hline & & 1: High upstream generation susceptibility \\
\hline & \multirow{2}{*}{ Slope } & 0: Slope $<\mathrm{t}_{1}$ \\
\hline & & 1: Slope $>t_{1}$ \\
\hline & \multirow{2}{*}{ Break of slope } & 0: Concave break of slope \\
\hline & & 1: Convex break of slope \\
\hline & \multirow{2}{*}{ Catchment compacity } & 0: Low Horton form factor \\
\hline & & 1: High Horton form factor \\
\hline & \multirow{2}{*}{ Artificial linear axes } & 0: No linear axes \\
\hline & & 1: Presence of linear axes \\
\hline \multirow{10}{*}{ Accumulation } & \multirow{2}{*}{$\begin{array}{c}\text { Upstream generation } \\
\text { susceptibility }\end{array}$} & 0: Low upstream generation susceptibility \\
\hline & & 1: High upstream generation susceptibility \\
\hline & \multirow{2}{*}{ Slope } & 0: Slope $>t_{1}$ \\
\hline & & 1: Slope $<\mathrm{t}_{1}$ \\
\hline & \multirow{2}{*}{ Break of slope } & 0: Convex break of slope \\
\hline & & 1: Concave break of slope \\
\hline & \multirow{2}{*}{ Topographic index } & 0: Topographic index $<\mathrm{t}_{2}$ \\
\hline & & 1: Topographic index $>t_{2}$ \\
\hline & \multirow{2}{*}{ Flow accumulation } & 0: Low flow accumulation \\
\hline & & 1: High flow accumulation \\
\hline
\end{tabular}




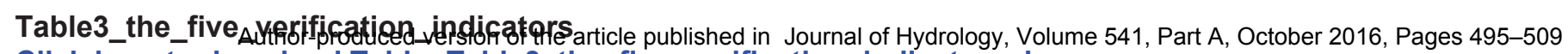

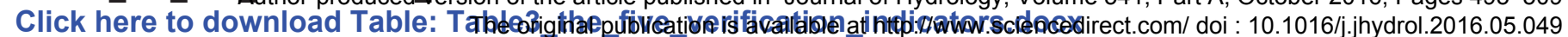

(C) This manuscript version is made available under the CC-BY-NC-ND 4.0 license

\begin{tabular}{|c|c|c|}
\hline $\begin{array}{l}\text { Verification } \\
\text { indicators }\end{array}$ & Formulas & Interpretation \\
\hline Accuracy & $\frac{\text { True positives }+ \text { True ne gatives }}{\text { Total }}$ & $\begin{array}{l}\text { Range: } 0 \text { to } 1 \\
\text { Perfect score: } 1\end{array}$ \\
\hline Bias & $\frac{\text { True positives }+ \text { False positives }}{\text { True positives }+ \text { False negatives }}$ & $\begin{array}{c}\text { Range: } 0 \text { to } \infty \\
\text { Perfect score: } 1 \\
<1 \text { underforecast, }>1 \text { overforecast }\end{array}$ \\
\hline Success ratio & $\frac{\text { True positives }}{\text { True positives }+ \text { False positives }}$ & $\begin{array}{l}\text { Range: } 0 \text { to } 1 \\
\text { Perfect score: } 1\end{array}$ \\
\hline $\begin{array}{l}\text { Probability of } \\
\text { detection }\end{array}$ & $\frac{\text { True positives }}{\text { True positives }+ \text { False negatives }}$ & $\begin{array}{l}\text { Range: } 0 \text { to } 1 \\
\text { Perfect score: } 1\end{array}$ \\
\hline False alarm ratio & $\frac{\text { False positives }}{\text { True positives }+ \text { False positives }}$ & $\begin{array}{l}\text { Range: } 0 \text { to } 1 \\
\text { Perfect score: } 0\end{array}$ \\
\hline
\end{tabular}




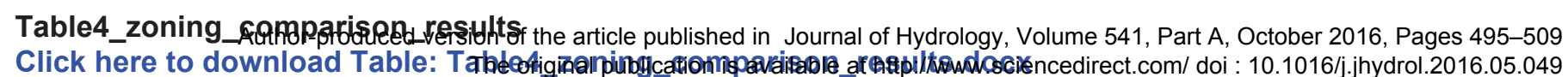

(C). This manuscript version is made available under the CC-BY-NC-ND 4.0 license

\begin{tabular}{|c|c|c|c|c|c|c|c|}
\hline \multirow{2}{*}{$\begin{array}{c}\text { IRIP } \\
\text { pixels }\end{array}$} & \multirow{2}{*}{$\begin{array}{c}\text { Verification } \\
\text { indicators }\end{array}$} & \multicolumn{2}{|c|}{$\begin{array}{c}\text { Surface runoff zoning / } \\
\text { Map of accumulation }\end{array}$} & \multicolumn{3}{|c|}{$\begin{array}{c}\text { Soil erosion zoning / Map } \\
\text { of transfer }\end{array}$} \\
\cline { 3 - 8 } & $0 \mathrm{~m}$ & $25 \mathrm{~m}$ & $50 \mathrm{~m}$ & $0 \mathrm{~m}$ & $25 \mathrm{~m}$ & $50 \mathrm{~m}$ \\
\hline \multirow{3}{*}{$\geq 4$} & Accuracy & 0.84 & 0.76 & 0.68 & 0.69 & 0.51 & 0.39 \\
\cline { 2 - 8 } & Bias & 0.41 & 0.25 & 0.18 & 0.12 & 0.07 & 0.06 \\
\cline { 2 - 8 } & Success ratio & 0.41 & 0.53 & 0.59 & 0.64 & 0.82 & 0.91 \\
\hline \multirow{3}{*}{$=5$} & Accuracy & 0.86 & 0.77 & 0.68 & 0.68 & 0.48 & 0.36 \\
\cline { 2 - 8 } & Bias & 0.06 & 0.04 & 0.03 & 0.01 & 0.00 & 0.00 \\
\cline { 2 - 8 } & Success ratio & 0.72 & 0.89 & 0.92 & 0.55 & 0.84 & 0.92 \\
\hline
\end{tabular}




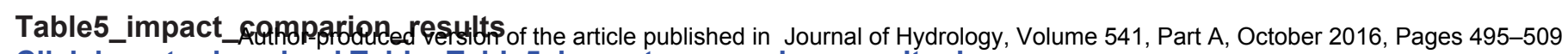

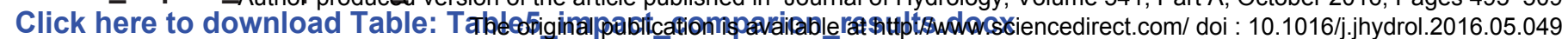
(C). This manuscript version is made available under the CC-BY-NC-ND 4.0 license

\begin{tabular}{|c|c|c|c|c|}
\hline \multirow{2}{*}{$\begin{array}{c}\text { Verification } \\
\text { indicators }\end{array}$} & \multicolumn{3}{|c|}{$\begin{array}{c}\text { Impacts on the transportation network / } \\
\text { Maps of transfer and accumulation }\end{array}$} \\
\cline { 2 - 5 } & \multicolumn{2}{|c|}{ Roads } & \multicolumn{2}{c|}{ Railways } \\
\cline { 2 - 5 } & $25 \mathrm{~m}$ & $50 \mathrm{~m}$ & $25 \mathrm{~m}$ & $50 \mathrm{~m}$ \\
\hline Accuracy & 0.68 & 0.65 & 0.34 & 0.30 \\
\hline Bias & 3.22 & 3.10 & 9.58 & 7.73 \\
\hline Success ratio & 0.23 & 0.23 & 0.08 & 0.12 \\
\hline Probability of detection & 0.73 & 0.72 & 0.80 & 0.90 \\
\hline False alarm ratio & 0.77 & 0.77 & 0.92 & 0.88 \\
\hline
\end{tabular}

